\title{
Management Effectiveness and Land Cover Change in Dynamic Cultural Landscapes-Assessing a Central European Biosphere Reserve
}

\author{
$\underline{\text { Bettina Ohnesorge }}^{1}$, Tobias Plieninger $^{2,3}{\text { and } \text { Patrick Hostert }^{3}}^{3}$
}

ABSTRACT. Protected areas are a central pillar of efforts to safeguard biodiversity and ecosystem services, but their contribution to the conservation and management of European cultural landscapes that have complex spatial-temporal dynamics is unclear. The conservation strategy of biosphere reserves aims at integrating biodiversity and ecosystem service conservation with economic development by designating zones of differing protection and use intensities. It is applied worldwide to protect and manage valuable cultural landscapes. Using the example of a German biosphere reserve, we developed a framework to assess the effectiveness of Central European reserves in meeting their land cover related management goals. Based on digital biotope maps, we defined and assessed land cover change processes that were relevant to the reserve management's goals over a period of 13 years. We then compared these changes in the reserve's core, buffer, and transition zones and in a surrounding reference area by means of a geographical information system. (Un-)desirable key processes related to management aims were defined and compared for the various zones. We found that-despite an overall land cover persistence of approximately $85 \%$ across all zones-differences in land cover changes can be more prominent across zones inside the reserve than between the areas inside and outside of it. The reserve as a whole performed better than the surrounding reference area when using land cover related management goals as a benchmark. However, some highly desirable targets, such as the conversion of coniferous plantations into seminatural forests or the gain of valuable biotope types, affected larger areas in the nonprotected reference area than in the transition zone.

Key Words: biosphere reserve; cultural landscape; land cover change; management effectiveness; protected area

\section{INTRODUCTION}

Land cover change, specifically conversion of natural habitats to agricultural cropland, is a process through which humankind is coming close to irreversibly transgressing planetary boundaries in the course of global environmental change (Rockström et al. 2009). In Europe, land cover change has been a long-lasting, comprehensive, and spatially expansive process, so that almost all of its land surface is considered to be cultural (i.e., anthropogenic) landscape today (Farina 2000, Plieninger and Bieling 2012). Many cultural landscapes have evolved gradually due to intensive interaction of people with land, and are generally characterized by longestablished practices that sustain a range of ecosystem services and high levels of biodiversity (Figueroa and Aronson 2006, Jones-Walters 2008, Takeuchi 2010). But over the past 50 to 60 years, the rate and magnitude of land cover change has greatly accelerated (Antrop 2004). On a global scale, land cover change has been predicted to have a greater impact on biodiversity loss in terrestrial ecosystems than climate change, nitrogen deposition, invasive species, or increased carbon dioxide concentrations (Sala et al. 2000).

A key strategy to control worldwide land cover change has been the establishment of protected areas (Lovejoy 2006). In 2004, the 7th Conference of the Parties to the Convention for Biological Diversity adopted the aim of establishing "a global network of comprehensive, representative and effectively managed national and regional protected area systems" (CBD 2004: Dec. VII/28) targeted at effectively conserving $10 \%$ of each of the world's ecological regions (CBD 2004: Dec. VII/30). Six years later, this goal was broadened to $17 \%$ of terrestrial and $10 \%$ of coastal and marine areas (CBD 2010: Dec. X/2). In fact, since 1990, the number of protected areas has increased by $58 \%$ and their extent by $48 \%$ (UN 2012). In $2010,13 \%$ of the world's terrestrial surface outside of Antarctica was covered by protected areas recorded in the World Database on Protected Areas (Bertzky et al. 2012). Presently, $18 \%$ of land in the European Union is included in the Natura 2000 network of protected areas. Among the various types of protected areas, biosphere reserves have been highlighted as particularly well-adapted instruments for the conservation of biodiversity in cultural landscapes because of their inclusive strategy (integrating land uses in different intensities and different land ownership types) and their designation of multiple management zones with different foci: from total protection to more development-oriented aims (Schliep and Stoll-Kleemann 2010).

Yet, despite their formal protection status, most nature reserves are far from protecting biodiversity effectively. Many protected areas have experienced a significant erosion of biodiversity that affects a broad range of taxa and ecosystem services (Laurance et al. 2012). The (in-)effectiveness of protected areas has been evaluated from global to regional 
scales (Leverington et al. 2010). Common effectiveness assessments refer to reserve design and management processes, while ecological integrity-in particular, ecosystem structure and functioning, ecosystem services, viability of plant and animal species, and land cover-has been infrequently investigated (Figueroa and Sánchez-Cordero 2008).

Protected areas are influenced not only by land cover change inside their borders but also by changes in areas surrounding them (Jones et al. 2009). Some comparative assessments of land cover change patterns in and around protected areas have been performed in tropical and subtropical regions, where the transformation of pristine landscapes, mainly through deforestation, is a primary process of change (Vasconcelos et al. 2002, Mas 2005, Figueroa and Sánchez-Cordero 2008, Figueroa et al. 2009). Most of these studies have focused on the capacity of protected areas to preserve ecosystems in their "natural" state by halting land cover change. One of the few assessments of land cover change in European protected areas concluded that most reserves have been effective at protecting ecosystems within their borders, even in areas subject to substantial land use pressures. Habitat degradation was generally slowed down more effectively in larger reserves, which points to a challenge for nature conservation in the small-scale land use mosaics of many parts of Europe (Maiorano et al. 2008).

In methodological terms, assessment of land cover change in protected areas is hampered by the fact that most studies have not included the land surrounding reserves as a control. Most studies that have included such comparison were based on an arbitrarily and inflexibly defined spatial buffer (e.g., $2 \mathrm{~km}$ ) around a reserve (Figueroa and Sánchez-Cordero 2008, Maiorano et al. 2008). However, environmental conditions, such as soil, slope, and distance to roads or settlements, can be far more influential on anthropogenic land cover change than an area's protection status. Therefore, it has been suggested that areas with comparable environmental characteristics be used as control sites rather than a mere spatial buffer (Mas 2005, Chowdhury 2006).

To our knowledge, assessments of the ability of biosphere reserves to manage land cover change have not yet been performed for European cultural landscapes. Also, existing studies from other parts of the world have mainly evaluated the effectiveness of simply preventing land cover change rather than relating their assessment of effectiveness to the specific management goals of protected areas. Given the inherent dynamics of cultural landscapes, we believe this to be a barrier for evaluating protected area effectiveness under European conditions. Furthermore, the effectiveness of different zones within biosphere reserves has rarely been addressed. Consequently, we aim to fill these gaps by contributing a quantitative and systematic assessment method for biosphere reserves that specifically considers management goals and zonation. Taking a German biosphere reserve as an example, we compare land cover change inside and outside the reserve and analyze how these changes relate to its defined management goals. In particular, we ask the following research questions:

- What net change and persistence of land cover is found in the different zones of the study area?

- What are the key change processes, and where do they occur?

- Are there differences in land cover change in the core, buffer, and transition zones compared to the area outside the biosphere reserve?

- How do these changes relate to the management goals of the reserve?

\section{METHODS}

\section{Study area}

The Upper Lusatian Heath and Pond Area ecoregion stretches across an area of about $20 \times 65 \mathrm{~km}$ in Saxony (eastern Germany), and shares its eastern border with Poland. It is part of the Saale glacial valley, characterized by a mosaic of sandy dunes and broad, marshy floodplains. Settlements $(5 \%)$ and agricultural land (53\%) are concentrated along the valleys and terraces, while lowlands and ridges are covered mainly by forests $(35 \%)$ and water bodies (5\%). The diverse mosaic of wetlands, marshlands, ponds, heather, dunes, and forests forms the third largest pond landscape in Europe. A peculiarity of the region is the large extent of human-made water bodies. Artificial ponds for carp farming were built as early as the 13th century. Until today, the complex system of ponds and ditches and its management have a major influence on landscape features and are important providers of biodiversity and ecosystem services. The water bodies constitute important breeding, resting, and wintering areas for many bird and amphibian species, and have an important influence on the landscape water regime (Biosphärenreservat Oberlausitzer Heide- und Teichlandschaft 1996). In the northern center of the ecoregion lies the Upper Lusatian Heath and Pond Landscape Biosphere Reserve, which was founded in 1994 and received UNESCO recognition in 1996 (Fig. 1) (Syrbe and Mannsfeld 2008). The reserve covers an area of 30,102 ha and includes four categories of management zones, each with individual management aims (Table 1). Foremost, $48 \%$ of the area is covered in forest, which in large parts consists of pine plantations. A major aim of the reserve management for all zones is to increase the proportion of more site-adapted deciduous forest. Lowland riparian and marshland forests, especially alder carr, are to be preserved. Altogether, the area covered in forest is supposed to be maintained below a threshold of 50\% of the whole reserve. About one-third of the 
Fig. 1. Position and zoning of the study and reference area. The border of the complete biosphere reserve is outlined in dark green.

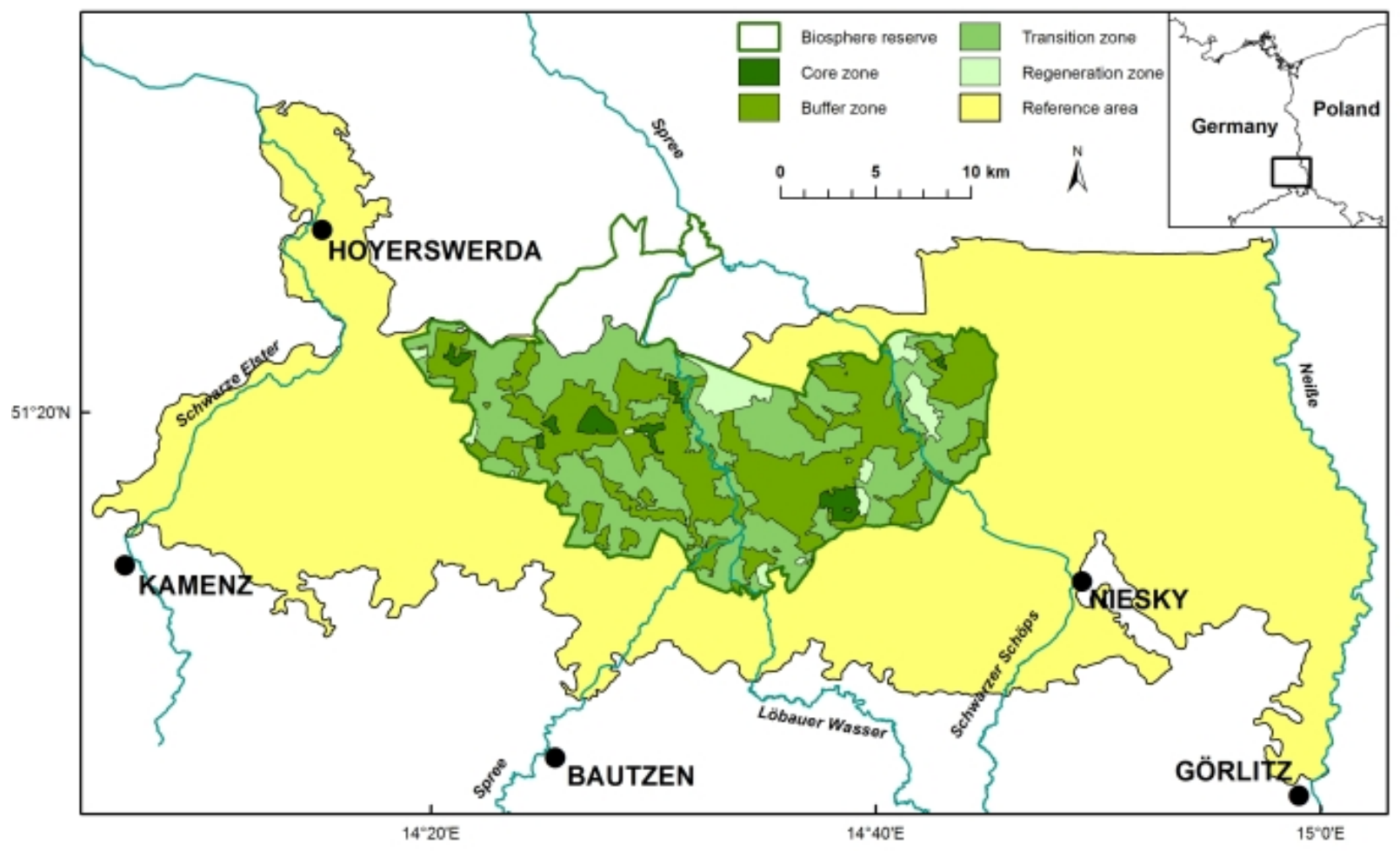

agricultural area consists of grassland. From the conservation perspective, the reserve's aim is to conserve and increase the area of extensively used grassland. Furthermore, especially in the buffer zone, conversion of the largest part of the available arable land into extensive grassland is desired (Biosphärenreservat Oberlausitzer Heide- und Teichlandschaft 2003).

\section{Study units}

For analysis of land cover change, the study area was divided into five spatial units: (1) the total area of the reserve; the areas of the (2) core, (3) buffer, and (4) transition zones; and (5) a reference (i.e., control) area around the reserve for comparison. We chose to compare areas of similar environmental conditions (Mas 2005), namely those within the same ecoregion. The ecoregion comprises an area of 109,889 ha, of which the reserve covers 26,972 ha. This reference area was considered large enough to serve as a baseline against which to judge differences in land cover (cf. Figueroa and Sánchez-Cordero 2008, Maiorano et al. 2008). The northernmost parts (3130 ha) and the so-called regeneration zone (2014 ha, in total) of the reserve were excluded from the analysis because they are situated in a different ecoregion or have been heavily affected by former open-cast mining and would thus potentially distort results (Fig. 1).

\section{Data base}

We used maps derived from very high spatial resolution airborne imagery for our change analysis. Aerial photographs were the only available very high resolution data source in the early 1990s and are still widely used today for monitoring nature reserves. The change period considered in our case covered approximately 13 years, and the geometric accuracy of the digital map products was unknown a priori. We therefore opted to combine post-classification change analysis with a rigorous error analysis to strictly rule out any errors beyond random effects that are inherent in any kind of change analysis (Lu et al. 2004, Pontius and Millones 2011). The digital land cover maps of the state of Saxony were provided by the Saxon Agency for the Environment, Agriculture and Geology. This data set consisted of vector data, which contained multi-level information on land cover, including the main group, subgroups, and information on specific traits and forms of utilization for each polygon (LfULG 1993, 2005). 
Table 1. Zones, functions, and management aims in the biosphere reserve (BR) (Biosphärenreservat Oberlausitzer Heide- und Teichlandschaft 1996, Syrbe et al. 1998, Bastian et al. 2005).

\begin{tabular}{|c|c|c|c|c|c|}
\hline Zone & Function & Description & Management aims & Size (ha) & $\%$ of BR \\
\hline Core zone & Total reserve & $\begin{array}{l}\text { Highly natural, mostly } \\
\text { marshes, bogs, carrs, inland } \\
\text { dunes }\end{array}$ & $\begin{array}{l}\text { No human influence or intrusion } \\
\text { allowed, except: extreme pest and fire } \\
\text { control, succession initialization, } \\
\text { research }\end{array}$ & 1,124 & 3.7 \\
\hline Buffer zone & Maintenance zone & $\begin{array}{l}\text { Ecologically important } \\
\text { pond areas and adjacent } \\
\text { forest, grassland, } \\
\text { floodplain, and heathland } \\
\text { areas }\end{array}$ & $\begin{array}{l}\text { Systematic landscape and biotope } \\
\text { management for balancing } \\
\text { conservation goals and economic } \\
\text { development, conversion of arable to } \\
\text { extensive grassland }\end{array}$ & 12,015 & 39.9 \\
\hline Transition zone & $\begin{array}{l}\text { Harmonic cultural } \\
\text { landscape }\end{array}$ & $\begin{array}{l}\text { All remaining agricultural, } \\
\text { forestry, and pond areas, } \\
\text { settlements }\end{array}$ & $\begin{array}{l}\text { Mainly structural changes: } \\
\text { fragmentation of agricultural land, } \\
\text { diminishing acre size, hedgerow } \\
\text { planting, conversion of pine and spruce } \\
\text { monoculture to mixed forest, } \\
\text { establishment of retention areas in } \\
\text { floodplains }\end{array}$ & 14,949 & 49.7 \\
\hline $\begin{array}{l}\text { Regeneration } \\
\text { zone }\end{array}$ & $\begin{array}{l}\text { Regeneration and } \\
\text { restoration }\end{array}$ & $\begin{array}{l}\text { Open cast mining or } \\
\text { extremely hydromeliorated } \\
\text { areas, unnaturally } \\
\text { constructed water bodies }\end{array}$ & $\begin{array}{l}\text { Restore ecological functionality in } \\
\text { areas heavily affected by } \\
\text { anthropogenic activities }\end{array}$ & 2,014 & 6.7 \\
\hline BR total & & & $\begin{array}{l}\text { Preserve carrs, lowland, and riparian } \\
\text { forest, increase fraction of deciduous } \\
\text { and mixed forest, keep forest cover } \\
\text { under } 50 \% \text { of total area, } \\
\text { conserve and increase area of } \\
\text { extensive grassland, } \\
\text { no decline in pond area, } \\
\text { in general, no extension of settlement } \\
\text { area }\end{array}$ & 30,102 & 100.0 \\
\hline
\end{tabular}

\section{Data analysis}

Bi-temporal change analysis is commonly used to describe land cover change based on very high resolution remote sensing data (Loveland 2012). Basically, there are two ways of handling such analyses-post-classification comparison and integrated analysis of an image stack (Coppin et al. 2004). While the latter is preferred in terms of error propagation control, post-classification analysis is the method of choice if leveling geometric or radiometric inaccuracies between different data sets is of prime importance. In this study, control of geometric inaccuracies concerning the digitized maps was the reason for doing a post-classification comparison (Coppin et al. 2004, Lu et al. 2004). Data were aggregated into 11 land cover classes (Table 2). The selection of classes was based on priority conservation goals, as stated in the reserve management plan. Beyond the management plan, we included oral information from biosphere reserve staff and more generic goals from the regional literature regarding land cover types that are valuable to biodiversity conservation and ecosystem services provision. A few areas ( $0.07 \%$ of the study area) had to be excluded from the analysis because no land cover information was available for them for the 1992 period. The vector data from 1992 and 2005 were intersected, which allowed a spatial tolerance of $8 \mathrm{~m}$ to account for digitization errors.

For each land cover class analyzed and in each spatial unit, the following parameters were calculated: total loss of area (ha), total gain (ha), net change (ha), persistence (ha), swap (ha), and percentages of the respective total and class areas. We followed Pontius et al. (2004) in their definition of swapping as being the case when the location of a category changes between time 1 and time 2 , while the quantity remains the same (no net loss or gain in the category but loss in one place and gain in another place). We also calculated the classwise relative changes between 2005 and 1992 because this relation is more meaningful for evaluating land cover changes of small classes than is the mere percentage of total change. For example, marshlands provide important ecosystem services in the reserve but cover only a small amount of its total area.

To calculate the area transitions between classes, we built a cross-tabulation matrix. In each study zone and for each combination of classes, we calculated the area of transition 
Table 2. Composition of classes analyzed.

\begin{tabular}{lll}
\hline \hline Class & Name & Categories in original data (LfULG 1992, 2005) \\
\hline S/I & Settlement, & Housing area, mixed settlement area, commercial area/technical infrastructure, urban green spaces, \\
& Infrastructure & traffic infrastructure \\
W & Water bodies & Flowing waters, still waters, water accompanying vegetation, buildings accompanying water \\
M/B & Marsh, Bog & Bogs, marshes \\
GLint & Grassland, intensive & Intensive, species-poor grassland; fat meadows \\
GLext & Grassland, extensive & Wet grassland, oligotrophic dry grassland \\
Ar & Arable land & Arable including fallow land, specialized crops, sewage fields \\
Fcon & Forest, coniferous & Pure coniferous forest, mixed coniferous forest \\
Fdec & Forest, deciduous & Pure deciduous forest, mixed deciduous forest \\
Fmix & Forest, mixed con/dec & Mixed, mainly deciduous forest; mixed, mainly coniferous forest \\
Fcarr & Riparian forest, Carr & Riparian forest, carr \\
W/H & Woodland, Heathland & Ruderal, rocks, open sandy, heathland, bushes, single tree groups, forest margins, pioneer forest, \\
& & reforestation, nonspecific forest \\
\hline
\end{tabular}

and the expected area in terms of loss (Pontius et al. 2004). This value shows the area a transition between two given classes would have covered had the area lost in one class been replaced randomly by all of the other classes according to their share of the total landscape. In addition, we calculated the relation of real loss divided by expected loss in order to estimate whether a transition between two given classes was more likely to occur (for values $>1$ ) or less likely to occur (values $<1$ ) than if randomly distributed (Appendix 1).

Based on the priority conservation goals, as stated in the management plan and derived through discussion with reserve managers, we defined six key processes (cf. Feranec et al. 2010), each of which denoted a transition of certain land cover classes on a given polygon from 1992 to 2005 (Table 3):

- Intensification: areas covered by extensive grassland in 1992 and by intensive grassland or arable land in 2005

- Extensification: areas covered by intensive grassland or arable land in 1992 and by extensive grassland in 2005

- Seminatural forest conversion: areas covered by coniferous forest in 1992 and by deciduous, mixed, or carr forest in 2005

- New infrastructure/soil sealing: areas covered by any class except settlements/infrastructure in 1992 and by settlements/infrastructure in 2005

- Gain of valuable biotopes: areas covered by settlements/ infrastructure, intensive grassland, extensive grassland, or arable land in 1992 and by water bodies, marshes, carr, or wood and heathland in 2005

- Loss of valuable biotopes: areas covered by water bodies, marshes, carr, or wood and heathland in 1992 and by intensive grassland, extensive grassland, or arable land in 2005
The absolute and relative changes for each zone of the protective area as well as the reference zone were summed. We then analyzed all changes relative to total area as well as relative to the area of the initial classes, where applicable.

\section{RESULTS}

\section{Overall patterns of land cover change}

Inside the biosphere reserve, various forest types (coniferous, deciduous, mixed, and riparian) were the dominant land cover in both 1992 (44\%) and 2005 (50\%) (Fig. 2). Fig. 3 shows that increase in forest cover by more than $5 \%$ of the total landscape was the largest net gain any land cover class experienced. Coniferous forests (mainly plantations of Pinus sylvestris) held the largest share in 1992 and 2005, with $35 \%$ and $37 \%$, respectively, and together with mixed forests showed the greatest net increase in area ( $2 \%$ of the landscape). Arable land was second in land cover inside the reserve in 1992 (19\%) but had gained only slightly less than $1 \%$ by 2005 . Intensive grassland, the third most dominant class, covered 13\% in 1992 and had the greatest net loss by 2005 (2\%). In the reference area, the most dominant class was arable land (33\% in 1992), followed by forest (30\% in 1992). Both arable land and all types of forest each gained approximately $2 \%$ of the landscape. Similar to the development inside the reserve, intensive grassland, starting from $17 \%$ in 1992, suffered the greatest net loss $(3 \%)$ in the reference area. In both areas, water bodies and built-up land (settlement, infrastructure) remained relatively stable.

\section{Transitions and persistence of land cover classes}

Overall persistence of land cover was relatively high (84-86\% of initial class areas) inside and outside the reserve as well as in each of the core, buffer, and transition zones (Table 4).

Of all classes, intensive grassland showed the greatest net loss inside and outside the reserve (14\% and $17 \%$, respectively). Inside, persistence was $72 \%$, and $14 \%$ were swapped. Outside, 
Table 3. Definition of key processes (for class abbreviations and descriptions, refer to Table 2).

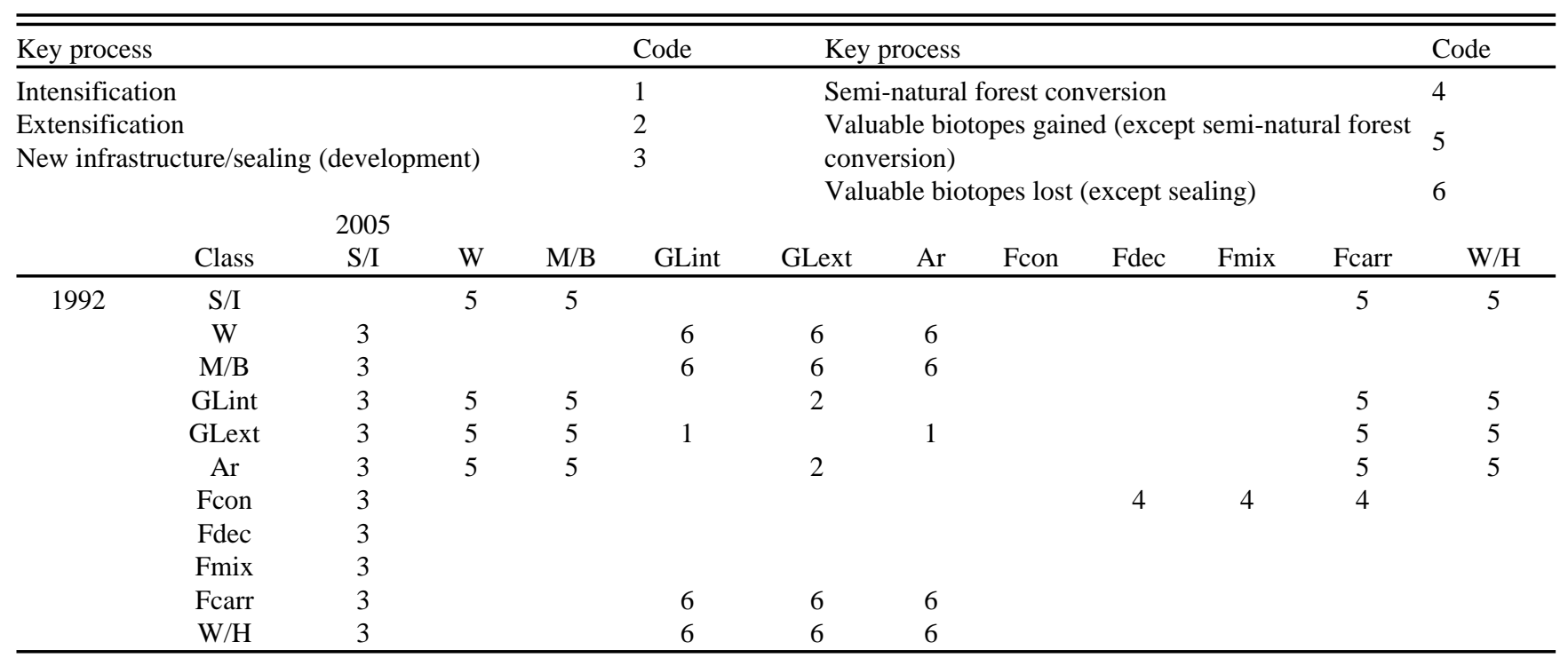

persistence was $68 \%$, and $15 \%$ were swapped. In the core zone, a $74 \%$ net loss was observed, while intensive grassland lost $13 \%$ of its original area in the buffer and transition zones.

Extensive grassland, which covered less than $1 \%$ of the inside and outside landscape areas in 1992, displayed considerable net gains of $67 \%$ (inside) and $36 \%$ (outside). At the same time, extensive grassland had the smallest persistence value inside and outside the reserve ( $52 \%$ and $50 \%$, respectively). Half of the 1992 extensive grassland was swapped to other locations. The largest net gain was in the transition zone (523\%).

Deciduous and mixed forest increased by $40 \%$ and $48 \%$, respectively, inside the reserve, while coniferous forest gained only $5 \%$. The core zone was the only zone where deciduous increased more than mixed forest ( $29 \%$ versus $20 \%)$. Outside the reserve, coniferous gained only slightly $(<1 \%)$, while deciduous forest showed a net gain of $22 \%$, and mixed forest gained $28 \%$. Of all classes, coniferous forest displayed the greatest persistence inside the reserve $(96 \%)$. Meanwhile, riparian forest suffered a slight loss $(<1 \%)$ inside but gained $17 \%$ outside the reserve.

Marshland and bogs covered only a small proportion inside and outside the reserve $(0.8 \%$ and $0.2 \%$, respectively). Therefore, small area changes for this class led to significant percentage changes. Inside the reserve, a net gain of $20 \%$ was found, while $28 \%$ was swapped and only $72 \%$ persisted. Outside, $11 \%$ of their original extent was lost, and there was little persistence $(56 \%)$ and a large share of swapping $(33 \%)$.

Water bodies showed great persistence at $96 \%$ both inside and outside the reserve, which made them one of the most stable land cover classes, in line with coniferous forest. Inside the reserve, they lost less than $1 \%$, while outside they gained a net $3 \%$. The greatest loss occurred in the core zone, where $16 \%$ net loss and a swap of $19 \%$ were measured.

Infrastructure lost a net $12 \%$ inside and $4 \%$ outside the reserve. Persistence was slightly below total persistence ( $83 \%$ outside, $79 \%$ inside). In the core zone, infrastructure experienced the greatest net loss $(84 \%)$, with only $16 \%$ persisting and no gain at all; in the buffer zone $67 \%$ of the infrastructure area disappeared. In the transition zone, however, $85 \%$ of the infrastructure persisted and only a net loss of $6 \%$ occurred.

Inside the reserve, arable land gained a net $3 \%$, and had a persistence of $90 \%$ and a $10 \%$ swap. Outside, similar developments were seen with a persistence of $92 \%$, an $8 \%$ swap, and a net gain of $6 \%$. Hardly any arable land was contained in the core zone.

Woodland and heathland showed little persistence inside and outside the reserve (25\% and $29 \%$, respectively), and lost $55 \%$ and $27 \%$ of coverage, respectively. Approximately $86 \%$ of woodland and heathland loss in the biosphere reserve and $78 \%$ in the reference area were due to transition from unspecified reforestation areas (which were not included in the different forest type classes) to coniferous, deciduous, or mixed forest.

\section{Key processes related to reserve management}

Table 5 reveals some differences in key land change processes (as defined by the reserve management plan) inside and outside of the biosphere reserve. For three of the six processes (intensification and extensification of cropland and grassland, and soil sealing), the areas inside the reserve performed better in terms of management goals than the reference area outside. We found no clear differences between inside and outside for seminatural forest conversion or loss of valuable biotopes. In 
Fig. 2. Land cover pattern in 1992 and 2005 and percentages of land cover classes in (A) the biosphere reserve and (B) the reference area.

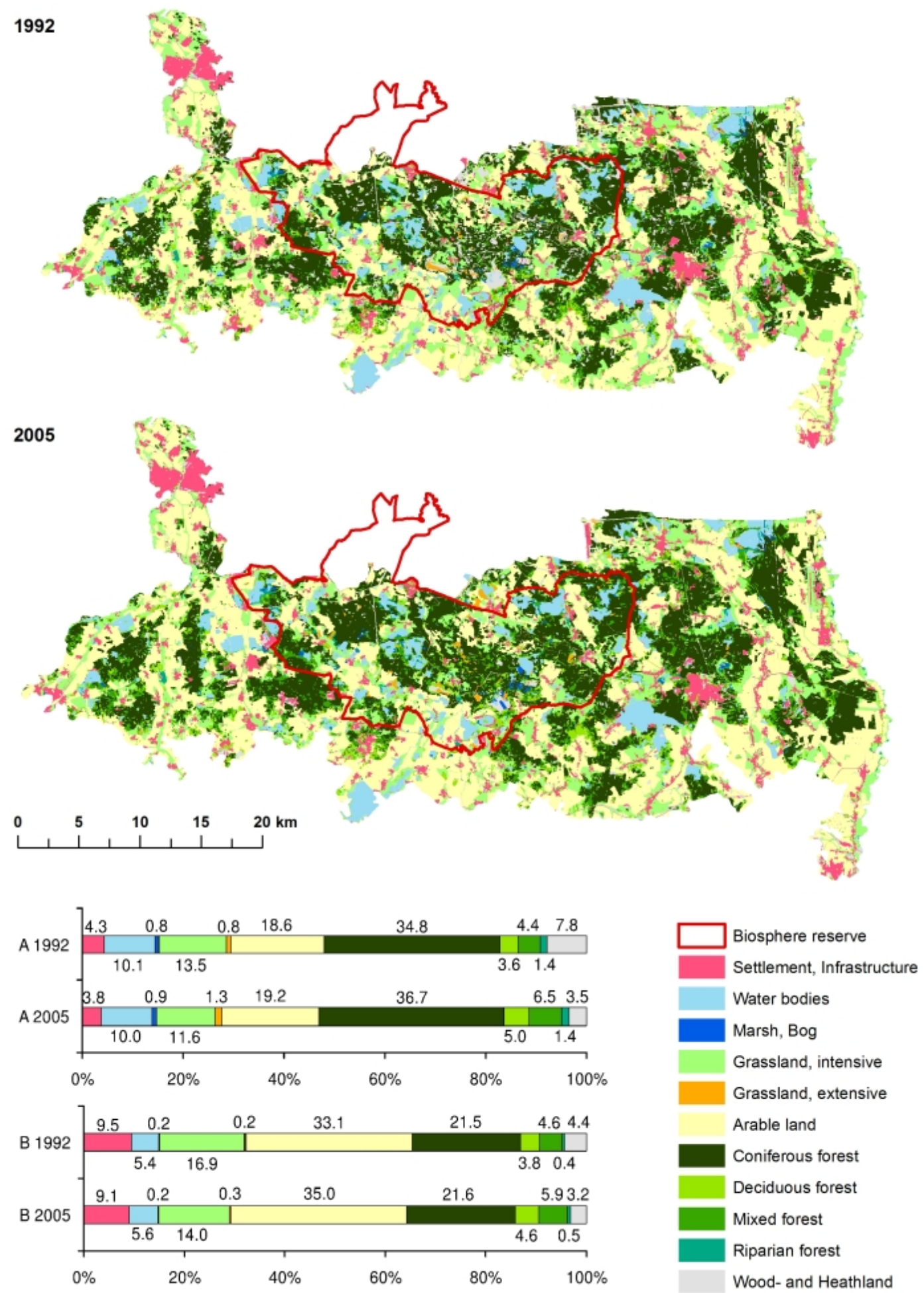


Fig. 3. Net changes in land cover classes (\% of landscape) between 1992 and 2005.

\section{Biosphere reserve}

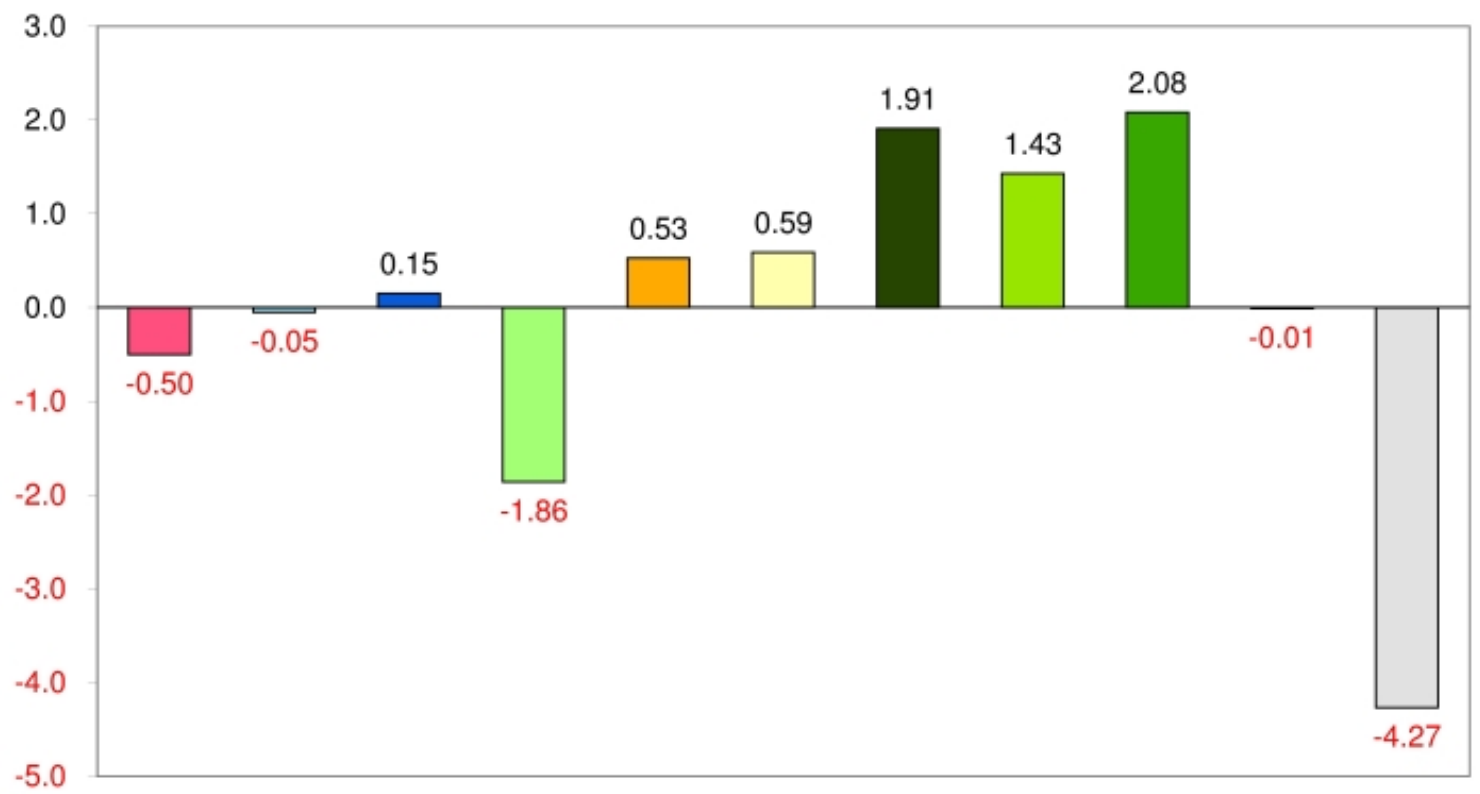

Reference area

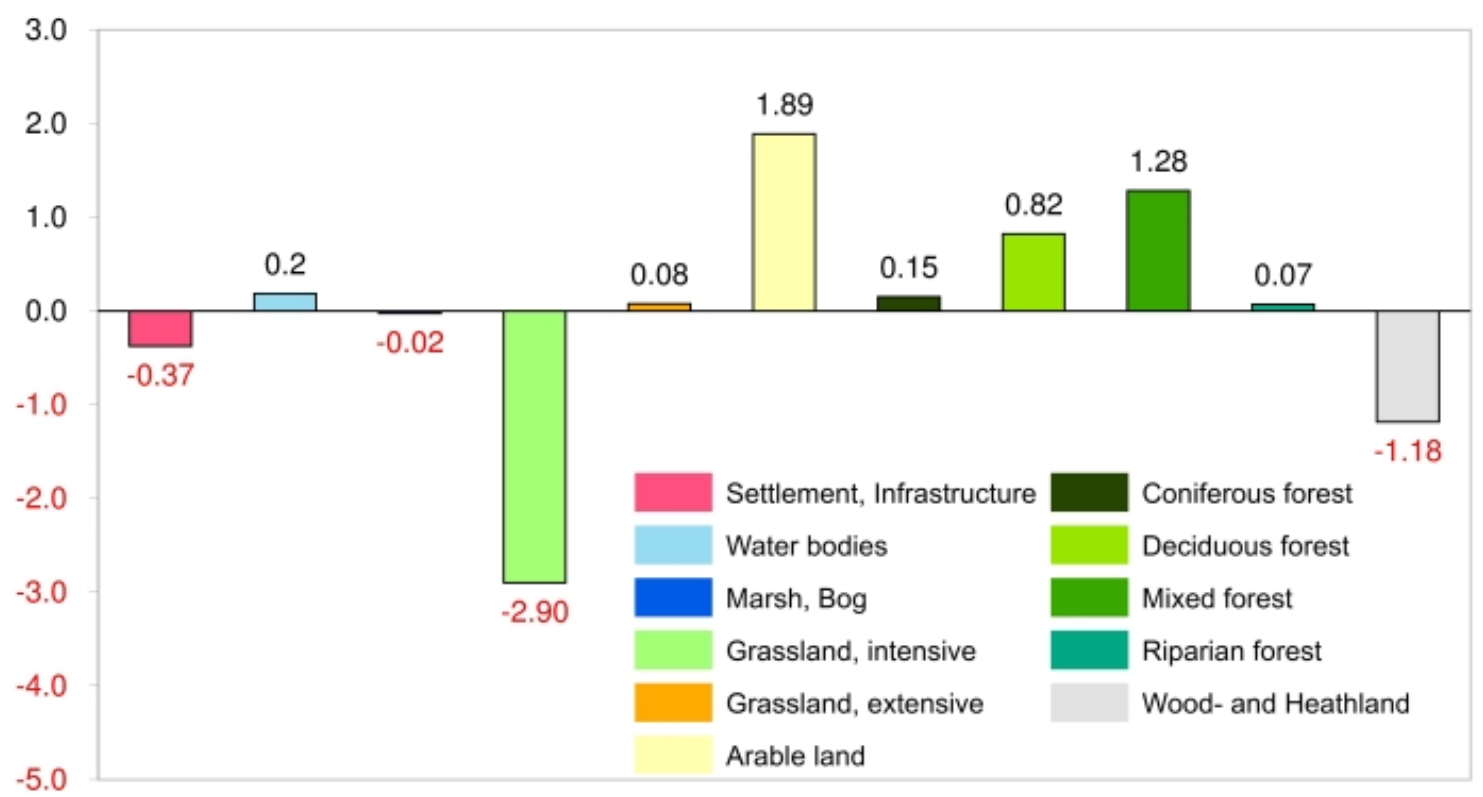

terms of gains in valuable biotope area (net change and percent), the reference zone corresponded better to the conservation management goals than did the reserve.
Table 6 shows the differences in key processes among the various zones and the reference zone. Land cover change in the core and buffer zones corresponded better to management 
Table 4. Net change in hectares (ha), net change (C), persistence (P), and swap (S) in percentage of area covered by the respective class in 1992.

\begin{tabular}{|c|c|c|c|c|c|c|c|c|c|c|c|c|c|c|c|c|c|c|c|c|}
\hline \multirow[b]{2}{*}{ Class } & \multicolumn{4}{|c|}{ Reference area } & \multicolumn{4}{|c|}{ Biosphere reserve } & \multicolumn{4}{|c|}{ Core zone } & \multicolumn{4}{|c|}{ Buffer zone } & \multicolumn{4}{|c|}{ Transition zone } \\
\hline & ha & $\mathrm{C}$ & $\mathrm{P}$ & $\mathrm{S}$ & ha & $\mathrm{C}$ & $\mathrm{P}$ & $S$ & ha & $\mathrm{C}$ & $\mathrm{P}$ & $S$ & ha & $\mathrm{C}$ & $\mathrm{P}$ & $S$ & ha & $\mathrm{C}$ & $\mathrm{P}$ & $\mathrm{S}$ \\
\hline $\begin{array}{l}\text { Grassland, } \\
\text { intensive }\end{array}$ & -2403 & -17 & 68 & 15 & -502 & -14 & 72 & 14 & -13 & -74 & 20 & 6 & -139 & -13 & 77 & 10 & -292 & -13 & 71 & 16 \\
\hline $\begin{array}{l}\text { Grassland, } \\
\text { extensive }\end{array}$ & 63 & 36 & 50 & 50 & 143 & 67 & 52 & 48 & 11 & 241 & 77 & 23 & 70 & 38 & 50 & 50 & 61 & 523 & 46 & 54 \\
\hline $\begin{array}{l}\text { Forest, } \\
\text { coniferous }\end{array}$ & 125 & 1 & 93 & 7 & 515 & 6 & 96 & 4 & 12 & 4 & 97 & 3 & 205 & 5 & 95 & 5 & 240 & 6 & 97 & 3 \\
\hline $\begin{array}{l}\text { Forest, } \\
\text { deciduous }\end{array}$ & 683 & 22 & 90 & 10 & 386 & 40 & 89 & 11 & 23 & 29 & 93 & 7 & 269 & 49 & 91 & 9 & 86 & 27 & 86 & 14 \\
\hline $\begin{array}{l}\text { Forest, } \\
\text { mixed }\end{array}$ & 1065 & 28 & 90 & 10 & 562 & 48 & 94 & 6 & 18 & 20 & 95 & 6 & 352 & 52 & 94 & 6 & 167 & 47 & 92 & 8 \\
\hline $\begin{array}{l}\text { Riparian } \\
\text { forest, Carr }\end{array}$ & 59 & 17 & 89 & 11 & -3 & -1 & 90 & 10 & 1 & 1 & 93 & 7 & -5 & -2 & 89 & 9 & 4 & 20 & 97 & 3 \\
\hline $\begin{array}{l}\text { Marsh, } \\
\text { Bog }\end{array}$ & -19 & -11 & 56 & 33 & 40 & 20 & 72 & 28 & 2 & 4 & 91 & 9 & 42 & 32 & 66 & 35 & -1 & -8 & 57 & 35 \\
\hline $\begin{array}{l}\text { Water } \\
\text { bodies }\end{array}$ & 154 & 3 & 96 & 4 & -13 & -1 & 96 & 4 & -2 & -16 & 65 & 19 & -12 & -1 & 97 & 3 & -2 & -1 & 89 & 11 \\
\hline $\begin{array}{l}\text { Settlement, } \\
\text { Infrastructure }\end{array}$ & -310 & -4 & 83 & 13 & -135 & -12 & 79 & 9 & -11 & -84 & 16 & 0 & -40 & -67 & 25 & 7 & -62 & -6 & 85 & 10 \\
\hline Arable land & 1565 & 6 & 93 & 8 & 159 & 3 & 90 & 10 & 0 & 0 & 0 & 0 & 18 & 4 & 80 & 20 & 92 & 2 & 90 & 10 \\
\hline $\begin{array}{l}\text { Woodland, } \\
\text { Heathland }\end{array}$ & -981 & -27 & 29 & 45 & -1152 & -55 & 25 & 20 & -41 & -47 & 41 & 12 & -760 & -66 & 22 & 12 & -294 & -40 & 28 & 32 \\
\hline Total & 0 & 0 & 85 & 15 & 0 & 0 & 84 & 16 & 0 & 0 & 86 & 15 & 0 & 0 & 84 & 16 & 0 & 0 & 85 & 15 \\
\hline
\end{tabular}

goals in terms of intensification and extensification of agricultural land than in the transition zone and reference area. Agricultural intensification was marginal $(<0.1 \%$ of the landscape, concentrated on a few relatively small and scattered patches) in the buffer and transition zones and the reference area but not at all in the core zone. The highest relative amount of agricultural intensification was found in the transition zone, where more than $36 \%$ of lands used extensively in 1992 were intensified, followed by the reference area with more than 27\%. The highest relative amount of agricultural extensification took place in the core zone $(67 \%)$. The reference area had the lowest amount of extensification in percent of the landscape and percent of originally intensively used land.

Regarding new infrastructure/soil sealing processes, the reserve also corresponded better to management goals than did the reference area. While the largest absolute and relative rates of new infrastructure development were observed in the reference area (with $1.3 \%$ of its total area being converted into built-up land), no areas were sealed in the core zone and hardly any $(<0.1 \%)$ were in the buffer zone. Most new built areas were converted from intensive grassland or arable land (Appendix 1).

Seminatural forest conversion took place on approximately $1 \%$ of the landscape inside and outside the reserve. In the buffer zone, the largest percentage of landscape was converted $(1.5 \%)$, whereas, related to original coniferous forest area, the largest share was converted in the reference area $(4.7 \%)$. The smallest conversion rate, related to total area and also to original coniferous area, was observed in the transition zone. In all zones, by far the largest share of converted coniferous forest was changed to mixed forest classes.

All zones gained significantly more valuable biotope areas than they lost in the studied period. The strongest net increase (gains minus losses) was found in the reference area (1.4\% of the landscape), closely followed by the core and transition zone (1.2\% each). Almost no loss occurred inside the core zone. Losses in the buffer, transition, and reference zones remained under $1 \%$, with the buffer zone losing most $(0.8 \%)$ and the transition zone losing the greatest share of original valuable biotopes $(4.5 \%)$. The biggest gain of valuable biotopes took place in the reference and transition zones.

\section{DISCUSSION}

\section{Effectiveness of biosphere reserve management in Upper Lusatia}

In broad terms, land cover distribution is relatively similar inside and outside the studied nature reserve. This indicates that establishment of the Upper Lusatia reserve is a textbook case of implementing the UNESCO Man and Biosphere philosophy that aims to protect nature within ordinary cultural landscapes rather than to set aside landscapes with outstanding natural characteristics. Settlement and infrastructure take up comparatively small shares because the study area is among the least densely populated and most geographically marginal areas of Germany. Forest and water bodies occupied larger 
Table 5. Comparison of key processes inside and outside the reserve $(\mathrm{A}=\%$ of total area covered, $\mathrm{B}=\%$ of total area covered by original classes in 1992, $\mathrm{C}=\%$ of original classes converted by process, bold $=$ best performance).

\begin{tabular}{|c|c|c|c|c|c|c|}
\hline \multirow[t]{2}{*}{ Process } & \multicolumn{3}{|c|}{ Biosphere reserve } & \multicolumn{3}{|c|}{ Reference area } \\
\hline & A (ha) & B (ha) & $\mathrm{C}$ & A (ha) & B (ha) & $\mathrm{C}$ \\
\hline Intensification & $0.0(12.1)$ & $0.8(211.9)$ & 5.7 & $0.1(47.7)$ & $0.2(174.6)$ & 27.3 \\
\hline Extensification & $0.5(145.6)$ & $32.1(8,658.1)$ & 1.7 & $0.1(108.9)$ & $50.0(41,468.2)$ & 0.3 \\
\hline Soil sealing & $0.4(109.1)$ & $4.3(1,158.8)$ & 9.4 & $1.3(1,037.7)$ & $9.5(7,861.5)$ & 13.2 \\
\hline Semi-natural forest conversion & $1.0(278.2)$ & $34.8(9,378.9)$ & 3.0 & $1.0(829.4)$ & $21.5(17,810.4)$ & 4.7 \\
\hline Valuable biotopes gained & $1.4(364.6)$ & $20.1(5,416.0)$ & 6.7 & $1.7(1,376.8)$ & $10.5(8,673.1)$ & 15.9 \\
\hline Valuable biotopes lost & $0.5(145.3)$ & $20.1(5,416.0)$ & 2.7 & $0.3(243.0)$ & $10.5(8,673.1)$ & 2.8 \\
\hline Valuable biotopes net change & $0.8(219.3)$ & & & $1.4(1,133.8)$ & & \\
\hline
\end{tabular}

shares within the nature reserve than outside, both before and after its official designation. Compared to global land cover transitions (Foley et al. 2005) and land change in other parts of the world, absolute change in land cover for the study area was relatively small over the 13 -year period, exhibiting an overall persistence of $84-85 \%$.

The increase in forest area by $6 \%$ of the landscape within the studied period-by 2005, almost reaching the threshold of $50 \%$ - is due mostly to natural succession of open woodland and heathlands and to reforestation. Because the management plan of the biosphere reserve aims at a forest cover of not more than $50 \%$ of total land area, specific management measures may be needed to halt further increases in forest area. Forest loss is obviously conceived to be less of a threat in the reserve than loss of other, valuable habitat types, such as heathland and dunes due to succession processes. The aim of increasing the deciduous and mixed share of forest in the reserve has been met in all three zones as well as the reference area, with little difference between the zones, and even the greatest share of originally coniferous forest having been converted in the reference area. On the one hand, the core and buffer zones already had a greater share of deciduous and mixed forest than the reference area in the first place, which left less room for improvement. On the other hand, the same incentive schemes for seminatural forest conversion apply to forest management both inside and outside the protected areas.

Similar driving forces also influence extensification and intensification inside and outside, including agrienvironmental schemes and legal provisions that restrict grassland to cropland conversion. After the breakdown of the socialist system, a dramatic drop in suckler-cow husbandry led to a decline in intensive grassland. Moreover, dairy cattle are hardly kept on grassland any more but rather in permanent housing systems. Nevertheless, we can see differences between the various zones in terms of cultivated land (extensification and intensification). To a certain degree, the differences in land cover development are the result of voluntary projects promoted by the reserve management. For example, 55 ha of wildflower meadows to support beekeeping and wild pollinators were created in cooperation with farmers and beekeepers. Also on a voluntary basis, the Förderverein Oberlausitz, a regional booster organization, manages approximately 500 ha of marsh and other valuable meadows. Another project initiated by the reserve is the cultivation of traditional cereal crops, and the special marketing thereof. The German Environment Foundation has acquired 3000 ha of forest in the reserve to manage in a conservation-oriented way.

Marshes and bogs, albeit of very small extent relative to the total area, showed clear differences in their development inside and outside the reserve. While in the reference area a net loss of $10 \%$ occurred, inside the reserve, marshes and bogs gained $20 \%$ over their original area. The increase in swampy areas may be due to several reasons. Historically, swamps made up about one-fifth of the area of the study region due to existing geological conditions and high groundwater levels. During the 1970s and 1980s, agricultural intensification brought about high levels of amelioration, and groundwater levels were lowered deliberately for the sake of lignite mining. In the drained soil, organic material became mineralized, and the soil subsided and literally sunk down. Following these extreme amelioration measures and after one of the large mining sites was closed down and flooded, groundwater levels slowly began to rise again, which resulted in the flooding of some areas. Today, in the core zone, no management measures apply, which has led to ditches being blocked by debris and sedimentation. Consequently, water levels have been rising further inside the core zone, and thus are affecting the surrounding buffer zone's water levels. The increase in swamps is therefore due to management measures and processes out of the reserve management's influence.

Looking at the development of our six key processes in the various zones under study, we see that processes have generally corresponded best to management goals in the core and buffer zones but less so in the transition zone. Exceptions were the gain of valuable biotopes and forest conversion, 
Table 6. Comparison of key processes in the three management zones and outside the reserve ( $\mathrm{A}=\%$ of total area covered, $\mathrm{B}=\%$ of total area covered by original classes in $1992, \mathrm{C}=\%$ of original classes converted by process, bold $=$ best performance) .

\begin{tabular}{|c|c|c|c|c|c|c|c|c|c|c|c|c|}
\hline \multirow[t]{2}{*}{ Process } & \multicolumn{3}{|c|}{ Core zone } & \multicolumn{3}{|c|}{ Buffer zone } & \multicolumn{3}{|c|}{ Transition zone } & \multicolumn{3}{|c|}{ Reference area } \\
\hline & $\begin{array}{r}\text { A } \\
\text { (ha) }\end{array}$ & $\begin{array}{r}\text { B } \\
\text { (ha) }\end{array}$ & $\mathrm{C}$ & $\begin{array}{r}\text { A } \\
\text { (ha) }\end{array}$ & $\begin{array}{r}\text { B } \\
\text { (ha) }\end{array}$ & $\mathrm{C}$ & $\begin{array}{r}\text { A } \\
\text { (ha) }\end{array}$ & $\begin{array}{r}\mathrm{B} \\
\text { (ha) } \\
\end{array}$ & $\mathrm{C}$ & $\begin{array}{r}\text { A } \\
\text { (ha) }\end{array}$ & $\begin{array}{r}\text { B } \\
\text { (ha) } \\
\end{array}$ & $\mathrm{C}$ \\
\hline Intensification & $\begin{array}{r}0.0 \\
(0.0)\end{array}$ & $\begin{array}{r}0.6 \\
(4.6)\end{array}$ & 0.0 & $\begin{array}{r}0.0 \\
(5.2)\end{array}$ & $\begin{array}{r}1.6 \\
(183.0)\end{array}$ & 2.9 & $\begin{array}{r}0.0 \\
(4.2)\end{array}$ & $\begin{array}{r}0.1 \\
(11.7)\end{array}$ & 36.1 & $\begin{array}{r}0.1 \\
(47.7)\end{array}$ & $\begin{array}{r}0.2 \\
(174.6)\end{array}$ & 27.3 \\
\hline Extensification & $\begin{array}{r}1.5 \\
(11.9)\end{array}$ & $\begin{array}{r}2.3 \\
(17.6)\end{array}$ & 67.4 & $\begin{array}{r}0.7 \\
(81.0)\end{array}$ & $\begin{array}{r}13.2 \\
(1,530.0)\end{array}$ & 5.3 & $\begin{array}{r}0.4 \\
(52.7)\end{array}$ & $\begin{array}{r}48.2 \\
(6,287.6)\end{array}$ & 0.8 & $\begin{array}{r}0.1 \\
(108.9)\end{array}$ & $\begin{array}{r}50.0 \\
(41,468.2)\end{array}$ & 0.3 \\
\hline Soil sealing & $\begin{array}{r}0.0 \\
(\mathbf{0 . 0})\end{array}$ & $\begin{array}{r}1.6 \\
(12.5)\end{array}$ & 0.0 & $\begin{array}{r}0.0 \\
(4.3)\end{array}$ & $\begin{array}{r}0.5 \\
(59.2)\end{array}$ & 7.3 & $\begin{array}{r}0.8 \\
(102.2)\end{array}$ & $\begin{array}{r}8.1 \\
(1,055.2)\end{array}$ & 9.7 & $\begin{array}{r}1.3 \\
(1,037.7)\end{array}$ & $\begin{array}{r}9.5 \\
(7,861.5)\end{array}$ & 13.2 \\
\hline $\begin{array}{l}\text { Semi-natural forest } \\
\text { conversion }\end{array}$ & $\begin{array}{r}1.1 \\
(8.9)\end{array}$ & $\begin{array}{r}45.1 \\
(352.4)\end{array}$ & 2.5 & $\begin{array}{r}1.5 \\
(175.5)\end{array}$ & $\begin{array}{r}39.0 \\
(4,525.8)\end{array}$ & 3.9 & $\begin{array}{r}0.6 \\
(84.1)\end{array}$ & $\begin{array}{r}31.3 \\
(4,078.1)\end{array}$ & 2.1 & $\begin{array}{r}1.0 \\
(829.4)\end{array}$ & $\begin{array}{r}21.5 \\
(17,810.4)\end{array}$ & 4.7 \\
\hline $\begin{array}{l}\text { Valuable biotopes } \\
\text { gained }\end{array}$ & $\begin{array}{r}1.2 \\
(9.7)\end{array}$ & $\begin{array}{r}28.9 \\
(226.0)\end{array}$ & 4.3 & $\begin{array}{r}1.1 \\
(125.7)\end{array}$ & $\begin{array}{r}35.2 \\
(4,090.0)\end{array}$ & 3.1 & $\begin{array}{r}1.5 \\
(198.5)\end{array}$ & $\begin{array}{r}7.1 \\
(930.9)\end{array}$ & 21.3 & $\begin{array}{r}1.7 \\
(1,376.8)\end{array}$ & $\begin{array}{r}10.5 \\
(8,673.1)\end{array}$ & 15.9 \\
\hline Valuable biotopes lost & $\begin{array}{r}0.0 \\
(0.1)\end{array}$ & $\begin{array}{r}28.9 \\
(226.0)\end{array}$ & 0.1 & $\begin{array}{r}0.8 \\
(96.5)\end{array}$ & $\begin{array}{r}35.2 \\
(4,090.0)\end{array}$ & 2.4 & $\begin{array}{r}0.3 \\
(42.2)\end{array}$ & $\begin{array}{r}7.1 \\
(930.9)\end{array}$ & 4.5 & $\begin{array}{r}0.3 \\
(243.0)\end{array}$ & $\begin{array}{r}10.5 \\
(8,673.1)\end{array}$ & 2.8 \\
\hline $\begin{array}{l}\text { Valuable biotopes net } \\
\text { change }\end{array}$ & $\begin{array}{r}1.2 \\
(9.6)\end{array}$ & & & $\begin{array}{r}0.3 \\
(29.2)\end{array}$ & & & $\begin{array}{r}1.2 \\
(156.2)\end{array}$ & & & $\begin{array}{r}1.4 \\
(1,133.8)\end{array}$ & & \\
\hline
\end{tabular}

which were well distributed over all zones. In general, the results for the change processes exhibit a gradual development from the core to the transition zone and eventually to the surrounding reference zone. In the case of intensification, share of valuable biotopes lost, and seminatural forest conversion, the transition zone was found to be even less effective in terms of management goals than was the surrounding reference zone.

For the future, considerable landscape dynamics may be expected for the area. Efforts of fostering conservationfriendly land management will certainly be ongoing. However, the area-just as land use in Germany in generalis strongly shifting toward intensification of agriculture (and partly also of forestry). A major driver is Germany's “energy shift" away from nuclear energy toward renewable energy uses, which provides powerful incentives for farmers to grow energy crops (Plieninger et al. 2006). In contrast, consumption of land for expansion of settlements and infrastructure areas will probably remain limited because population numbers in the study area are likely to further decrease. This development, together with a likely reduction in available public funds for nature conservation measures, will pose challenges on professional reserve managers and voluntary conservation activists to retain the high nature value of the reserve, which to a large degree depends on continued conservation management.

\section{Insight into the ability of protected areas to control land cover change}

Taken together, our results indicate a remarkable effectiveness of the reserve to manage key land change processes along desired paths. The findings are in line with the results of a meta-analysis of 49 protected areas in 22 countries (Nagendra 2008), where most protected areas in North America and Europe exhibited desired directions of land cover change. In an assessment of 716 protected areas in Italy, based on CORINE land cover data, Maiorano et al. (2008) demonstrated that the observed areas were effective at slowing down land cover change compared to their surroundings. Their findings suggested that only in a change towards more artificial land cover classes do differences become evident, but in change towards more natural cover classes, differences between protected areas and their surroundings do not emerge. Our results partly back up these findings: in contrast to intensification, soil sealing, and valuable biotopes lost, the protected zones in our study area did not exhibit better development in terms of relative and net gain of valuable biotopes.

The studied period corresponds with Eastern Germany's tumultuous transition period following the end of communism. Compared to other European countries affected by similar political changes, the forest cover in all zones exhibited remarkable persistence of up to $97 \%$. Net increase in forest area was greater than, for example, the numbers that Kuemmerle et al. (2009b) found in Romania during a similar time span (1990-2005). A major difference to other countries in the formerly socialist Central and Eastern Europe (Kuemmerle et al. 2009a) may be in German forestry legislation, which was quickly adopted in the early 1990s and effectively controls illegal logging and forest conversion. At the national level, Germany experienced hardly any change in total forest cover between 1990 and 2005, with a slight tendency toward forest expansion (FAO 2006). 
As Ewers and Rodrigues (2008) argue, the conservation success of a protected area is likely to have an adverse impact on the land directly surrounding it, which in our case is the transition zone that is not formally protected by law, as opposed to the core and buffer zones of the reserve. Moreover, studies from other parts of the world have shown that development on land surrounding protected areas has a significant influence on what happens inside those protected areas (Hansen and DeFries 2007, Leroux and Kerr 2012). Especially, smaller protected areas have been found to be part of larger socioeconomic systems, and follow the development trends those systems provide (Maiorano et al. 2008). The proximity to settlements is another factor that influences conservation success in and around protected areas (Alados et al. 2004, Nagendra et al. 2010). Thus, a less rigid protection status, spatial proximity to settlements, and possibly leakage effects are likely to explain why the transition zone shows very similar or even worse results than the reference area. On the other hand, the strict protection status of the core zone is also likely to influence the buffer zone positively in some respects, as in the example of wetland propagation around the core zone. Walker and Solecki (1999) found quite similar results for a biosphere reserve in the U.S. Like the Upper Lusatia, the New Jersey Pinelands reserve is embedded in an actively used cultural landscape. Similar to the results of our study, their calculations regarding land conversion and development reveal a clear graduation from the core to the transition zone, with an even higher percentage of converted land in the transition zone than in the surrounding control areas. These results were to a large extent due to the reserve's management rather than to other factors, such as population and household growth or land supply and demand.

\section{Remaining uncertainties}

The accuracy of our assessment depends to a high degree on the resolution of the available data. We were lucky to be able to use land cover maps that are publicly available in Saxony and show a high resolution compared to, for example, the CORINE land cover data used in many similar assessments in Europe. The validity of the given data must however be regarded with caution. Classification errors cannot be ruled out completely, but a formal accuracy assessment has not been carried out by the responsible state agency. We observed, for example, high degrees of swapping in swamps, especially with water, extensive grassland, and carr. Compared to 1992, which was a period with very little rainfall in the region, 2005 was a very wet season. We cannot rule out classification errors due to some meadow or forest areas being mistakenly classified as swamp in 2005 or vice versa. Similar difficulties were apparent for intensive grassland and arable land laying fallow. Summarizing water and marsh/bog in the "valuable biotopes gained/lost" processes and arable/intensive in the "intensification/extensification" processes has helped minimize that bias.
Another important point to consider is that land cover change is only one of several stressors of protected areas. Many other threats are more subtle (e.g., increase in fertilizer and pesticide inputs on arable land, water pollution, grazing management) and cannot be grasped through land cover change analysis. Also, our study focuses exclusively on the spatial extent of land cover changes, meaning for example that small-scale changes in standing biomass within one land cover class or the quality of water bodies were not considered in the assessment.

When assessing the effectiveness of a protected area by comparing land cover change processes inside and outside its boundaries, leakage effects may be a confounding factor but could not be grasped in our study design. It is a common phenomenon that the restriction of land use activities inside a protected area can prompt a mere shift of these activities to other sites instead of halting them, thus causing a stronger negative impact outside the reserve. We therefore have to consider the effects a reserve may have on a wider area than merely within its own boundaries. The same effect can also create bias in evaluating the relative effectiveness of a reserve in comparison to adjacent reference zones (Ewers and Rodrigues 2008, Dewi et al. 2013).

The time span covered in this study also needs to be justified. The 1992-2005 period marks the first 13 years of reserve management in Upper Lusatia. Going further back in time would not have yielded much more information on management effectiveness because the reserve did not exist before 1992. At the same time, coinciding with the years following German unification, this was a period of great political and socioeconomic change with potentially high land use dynamics (Schleyer and Plieninger 2011, Plieninger et al. 2012) and was therefore of interest to us. Good data availability further backed up the decision in favor of this comparably short time span.

\section{CONCLUSION}

There is an abundance of studies on land cover change in protected areas in tropical forest ecosystems which have focused mainly on deforestation and forest degradation (Nagendra et al. 2010, Mehring and Stoll-Kleemann 2011, Barber et al. 2012). In the context of Central European cultural landscapes, deforestation rates or overall land cover change are not suitable indicators of management (in-)effectiveness because these landscapes have been shaped and characterized by dynamic human uses and ongoing alteration for centuries (Antrop 2005). The abundant variety of ecosystem services that these landscapes provide is to a great degree dependent on human use and influence on the landscape. Studies of reserve effectiveness that acknowledge the peculiarities of such inherent landscape dynamics are largely missing. Our study has incorporated these specifics by defining and assessing (un)desired key processes of land cover change in 
such landscapes. Considering processes rather than a static reference condition has proved to be a useful means of assessing the success of biosphere reserve management.

Responses to this article can be read online at: http://www.ecologyandsociety.org/issues/responses. $\mathrm{php} / 5888$

\section{Acknowledgments:}

We gratefully acknowledge support from the German Ministry of Education and Research (FKZ 01UU0904A) and the European Commission (Project HERCULES, grant agreement no. 603447, FP7-ENV-2013-two-stage). We thank Peter Heyne, Manuel Weis, and Ulrich Tetzel for providing valuable information on the history and presence of land use and forest management in the biosphere reserve. Christian Schleyer provided many helpful comments throughout the study, and Christopher Hank improved the language of the manuscript. Martin Mantel and Benedikt Ibele were of great help with formatting figures and tables.

\section{LITERATURE CITED}

Alados, C. L., Y. Pueyo, O. Barrantes, J. Escos, L. Giner, and A. B. Robles. 2004. Variations in landscape patterns and vegetation cover between 1957 and 1994 in a semiarid Mediterranean ecosystem. Landscape Ecology 19:543-559. http://dx.doi.org/10.1023/B:LAND.0000036149.96664.9a

Antrop, M. 2004. Landscape change and the urbanization process in Europe. Landscape and Urban Planning 67:9-26. http://dx.doi.org/10.1016/S0169-2046(03)00026-4

Antrop, M. 2005. Why landscapes of the past are important for the future. Landscape and Urban Planning 70:21-34. http://dx.doi.org/10.1016/j.landurbplan.2003.10.002

Barber, C. P., M. A. Cochrane, C. Souza, Jr., and A. Veríssimo. 2012. Dynamic performance assessment of protected areas. Biological Conservation 149:6-14. http://dx.doi.org/10.1016/ j.biocon.2011.08.024

Bastian, O., H. T. Porada, M. Röder, and R.-U. Syrbe. 2005. Oberlausitzer Heide- und Teichlandschaft. Böhlau Verlag, Wien, Austria; Köln, Weimar, Germany.

Bertzky, B., C. Corrigan, J. Kemsey, S. Kenney, C. Ravilious, C. Besançon, and N. Burgess. 2012. Protected planet report 2012: tracking progress towards global targets for protected areas. IUCN, Gland, Switzerland and UNEP-WCMC, Cambridge, UK.

Biosphärenreservat Oberlausitzer Heide- und Teichlandschaft. 1996. Biosphärenreservatsplan - Teil 1. Mücka, Germany.
Biosphärenreservat Oberlausitzer Heide- und Teichlandschaft. 2003. Biosphärenreservatsplan - Teil 2: Rahmenkonzept für Schutz, Pflege und Entwicklung. Mücka, Germany.

Chowdhury, R. R. 2006. Landscape change in the Calakmul Biosphere Reserve, Mexico: modeling the driving forces of smallholder deforestation in land parcels. Applied Geography 26:129-152. http://dx.doi.org/10.1016/j.apgeog.2005.11.004

Convention on Biological Diversity (CBD). 2004. Decisions adopted by the Conference of the Parties to the Convention on Biological Diversity at its seventh meeting. [online] URL: http://www.cbd.int/decisions/cop/?m=cop-07

Convention on Biological Diversity (CBD). 2010. Decisions adopted by the Conference of the Parties to the Convention on Biological Diversity at its tenth meeting. [online] URL: http://www.cbd.int/decisions/cop/?m=cop-10

Coppin, P., I. Jonckheere, K. Nackaerts, B. Muys, and E. Lambin. 2004. Digital change detection methods in ecosystem monitoring: a review. International Journal of Remote Sensing 25:1565-1596. http://dx.doi.org/10.1080/0143116031000101675

Dewi, S., M. van Noordwijk, A. Ekadinata, and J. L. Pfund. 2013. Protected areas within multifunctional landscapes: squeezing out intermediate land use intensities in the tropics? Land Use Policy 30:38-56. http://dx.doi.org/10.1016/j. landusepol.2012.02.006

Ewers, R. M., and A. S. L. Rodrigues. 2008. Estimates of reserve effectiveness are confounded by leakage. Trends in Ecology \& Evolution 23:113-116. http://dx.doi.org/10.1016/ j.tree.2007.11.008

Farina, A. 2000. The cultural landscape as a model for the integration of ecology and economics. Bioscience 50:313320. http://dx.doi.org/10.1641/0006-3568(2000)050\%5B0313: TCLAAM\%5D2.3.CO;2

Feranec, J., G. Jaffrain, T. Soukup, and G. Hazeu. 2010. Determining changes and flows in European landscapes 19902000 using CORINE land cover data. Applied Geography 30:19-35. http://dx.doi.org/10.1016/j.apgeog.2009.07.003

Figueroa B., and J. Aronson. 2006. New linkages for protected areas: making them worth conserving and restoring. Journal for Nature Conservation 14:225-232. http://dx.doi. org/10.1016/j.jnc.2006.04.007

Figueroa, F., and V. Sánchez-Cordero. 2008. Effectiveness of natural protected areas to prevent land use and land cover change in Mexico. Biodiversity and Conservation 17:32233240. http://dx.doi.org/10.1007/s10531-008-9423-3

Figueroa, F., V. Sánchez-Cordero, J. A. Meave, and I. Trejo. 2009. Socioeconomic context of land use and land cover change in Mexican biosphere reserves. Environmental Conservation 36:180-191. http://dx.doi.org/10.1017/ $\underline{\text { S0376892909990221 }}$ 
Foley, J. A., R. DeFries, G. P. Asner, C. Barford, G. Bonan, S. R. Carpenter, F. S. Chapin, M. T. Coe, G. C. Daily, H. K. Gibbs, J. H. Helkowski, T. Holloway, E. A. Howard, C. J. Kucharik, C. Monfreda, J. A. Patz, I. C. Prentice, N. Ramankutty, and P. K. Snyder. 2005. Global consequences of land use. Science 309:570-574. http://dx.doi.org/10.1126/ science. 1111772

Food and Agriculture Organization of the United Nations (FAO). 2006. Global forest resources assessment: main report. Food and Agriculture Organization of the United Nations, Rome, Italy.

Hansen, A. J., and R. DeFries. 2007. Ecological mechanisms linking protected areas to surrounding lands. Ecological Applications 17:974-988. http://dx.doi.org/10.1890/05-1098

Jones, D. A., A. J. Hansen, K. Bly, K. Doherty, J. P. Verschuyl, J. I. Paugh, R. Carle, and S. J. Story. 2009. Monitoring land use and cover around parks: a conceptual approach. Remote Sensing of Environment 113:1346-1356. http://dx.doi. org/10.1016/j.rse.2008.08.018

Jones-Walters, L. 2008. Biodiversity in multifunctional landscapes. Journal for Nature Conservation 16:117-119. http://dx.doi.org/10.1016/j.jnc.2008.03.001

Kuemmerle, T., O. Chaskovskyy, J. Knorn, V. C. Radeloff, I. Kruhlov, W. S. Keeton, and P. Hostert. 2009a. Forest cover change and illegal logging in the Ukrainian Carpathians in the transition period from 1988 to 2007. Remote Sensing of Environment 113:1194-1207. http://dx.doi.org/10.1016/j. $\underline{\text { rse.2009.02.006 }}$

Kuemmerle, T., D. Müller, P. Griffiths, and M. Rusu. 2009b. Land use change in Southern Romania after the collapse of socialism. Regional Environmental Change 9:1-12. http://dx. doi.org/10.1007/s10113-008-0050-Z

Laurance, W. F., D. C. Useche, J. Rendeiro, M. Kalka, C. J. A. Bradshaw, S. P. Sloan, S. G. Laurance, M. Campbell, K. Abernethy, P. Alvarez, et al. 2012. Averting biodiversity collapse in tropical forest protected areas. Nature 489:290294. http://dx.doi.org/10.1038/nature11318

Leroux, S. J., and J. T. Kerr. 2012. Land development in and around protected areas at the wilderness frontier. Conservation Biology 27:166-176. http://dx.doi.org/10.1111/ j.1523-1739.2012.01953.x

Leverington, F., K. L. Costa, H. Pavese, A. Lisle, and M. Hockings. 2010. A global analysis of protected area management effectiveness. Environmental Management 46:685-698. http://dx.doi.org/10.1007/s00267-010-9564-5

LfULG 1993. Biotoptypen- und Landnutzungskartierung 1992/1993. Saxon Agency für Environment, Agriculture and Geology, Dresden, Germany.
LfULG 2005. Biotoptypen- und Landnutzungskartierung 2005. Saxon Agency für Environment, Agriculture and Geology, Dresden, Germany.

Lovejoy, T. E. 2006. Protected areas: a prism for a changing world. Trends in Ecology \& Evolution 21:329-333. http://dx. doi.org/10.1016/j.tree.2006.04.005

Loveland, T. R. 2012. History of land-cover mapping. Pages 13-22 in C. P. Giri, editor. Remote sensing of land use and land cover. CRC Press, Boca Raton, USA. http://dx.doi.org/ http://dx.doi.org/10.1201/b11964-4

Lu, D., P. Mausel, E. Brondizio, and E. Moran. 2004. Change detection techniques. International Journal of Remote Sensing 25:2365-2401. http://dx.doi.org/10.1080/0143116031000139863

Maiorano, L., A. Falcucci, and L. Boitani. 2008. Sizedependent resistance of protected areas to land-use change. Proceedings of the Royal Society B-Biological Sciences 275:1297-1304. http://dx.doi.org/10.1098/rspb.2007.1756

Mas, J. F. 2005. Assessing protected area effectiveness using surrounding (buffer) areas environmentally similar to the target area. Environmental Monitoring and Assessment 105:69-80. http://dx.doi.org/10.1007/s10661-005-3156-5

Mehring, M., and S. Stoll-Kleemann. 2011. How effective is the buffer zone? Linking institutional processes with satellite images from a case study in the Lore Lindu Forest Biosphere Reserve, Indonesia. Ecology and Society 16(4):3. http://dx. doi.org/10.5751/ES-04349-160403

Nagendra, H. 2008. Do parks work? Impact of protected areas on land cover clearing. Ambio 37:330-337. http://dx.doi. org/10.1579/06-R-184.1

Nagendra, H., D. Rocchini, and R. Ghate. 2010. Beyond parks as monoliths: spatially differentiating park-people relationships in the Tadoba Andhari Tiger Reserve in India. Biological Conservation 143:2900-2908. http://dx.doi.org/10.1016/j. biocon.2010.04.050

Plieninger, T., O. Bens, and R. F. Hüttl. 2006. Perspectives of bioenergy for agriculture and rural areas. Outlook on Agriculture 35:123-127.

Plieninger, T., and C. Bieling, editors. 2012. Resilience and the cultural landscape: understanding and managing change in human-shaped environments. Cambridge University Press, Cambridge, UK. http://dx.doi.org/10.1017/CBO9781139107778

Plieninger, T., C. Schleyer, M. Mantel, and P. Hostert. 2012. Is there a forest transition outside forests? Trajectories of farm trees and effects on ecosystem services in an agricultural landscape in Eastern Germany. Land Use Policy 29:233-243. http://dx.doi.org/10.1016/j.landusepol.2011.06.011

Pontius, R. G., and M. Millones. 2011. Death to Kappa: birth of quantity disagreement and allocation disagreement for 
accuracy assessment. International Journal of Remote Sensing 32:4407-4429. http://dx.doi.org/10.1080/01431161.2011.552923

Pontius, R. G., E. Shusas, and M. McEachern. 2004. Detecting important categorical land changes while accounting for persistence. Agriculture, Ecosystems \& Environment 101:251-268. http://dx.doi.org/10.1016/j.agee.2003.09.008

Rockström, J., W. Steffen, K. Noone, Å. Persson, F. S. Chapin, III, E. F. Lambin, T. M. Lenton, M. Scheffer, C. Folke, H. J. Schellnhuber, B. Nykvist, C. A. de Wit, T. Hughes, S. van der Leeuw, H. Rodhe, S. Sörlin, P. K. Snyder, R. Costanza, U. Svedin, M. Falkenmark, L. Karlberg, R. W. Corell, V. J. Fabry, J. Hansen, B. Walker, D. Liverman, K. Richardson, P. Crutzen, and J. A. Foley. 2009. A safe operating space for humanity. Nature 461:472-475. http://dx.doi.org/10.1038/461472a

Sala, O. E., F. S. Chapin, III, J. J. Armesto, E. Berlow, J. Bloomfield, R. Dirzo, E. Huber-Sanwald, L. F. Huenneke, R. B. Jackson, A. Kinzig, R. Leemans, D. M. Lodge, H. A. Mooney, M. Oesterheld, N. L. Poff, M. T. Sykes, B. H. Walker, M. Walker, and D. H. Wall. 2000. Global biodiversity scenarios for the year 2100. Science 287:1770-1774. http:// dx.doi.org/10.1126/science.287.5459.1770

Schleyer, C., and T. Plieninger. 2011. Obstacles and options for the design and implementation of payment schemes for ecosystem services provided through farm trees in Saxony, Germany. Environmental Conservation 38:454-463. http:// dx.doi.org/10.1017/S0376892911000361

Schliep, R., and S. Stoll-Kleemann. 2010. Assessing governance of biosphere reserves in Central Europe. Land Use Policy 27:917-927. http://dx.doi.org/10.1016/j.

landusepol.2009.12.005

Syrbe, R.-U., O. Bastian, and M. Röder. 1998. Analyse und Bewertung der Landschaft und ihrer Veränderungen anhand ausgewählter Funktionen des Naturhaushaltes im Biosphärenreservat "Oberlausitzer Heide- und Teichlandschaft,.. Pages 267-303 in K.-H. Erdmann, H.-R. Bork, and K. Grunewald, editors. Geographie und Naturschutz. Beiträge zu einer naturverträglichen Entwicklung. Bundesamt für Naturschutz, Bonn, Germany.

Syrbe, R.-U., and K. Mannsfeld. 2008. Oberlausitzer Heideund Teichgebiet. Pages 57-64 in K. Mannsfeld and R.-U. Syrbe, editors. Naturräume in Sachsen. Deutsche Akademie für Landeskunde, Leipzig, Germany.

Takeuchi, K. 2010. Rebuilding the relationship between people and nature: the Satoyama Initiative. Ecological Research 25:891-897. http://dx.doi.org/10.1007/s11284-010-0745-8

United Nations (UN). 2012. The millennium development goals report 2012. United Nations, New York, USA.
Vasconcelos, M. J. P., J. C. M. Biai, A. Araujo, and M. A. Diniz. 2002. Land cover change in two protected areas of Guinea-Bissau (1956-1998). Applied Geography 22:139156. http://dx.doi.org/10.1016/S0143-6228(02)00005-X

Walker, R. T., and W. D. Solecki. 1999. Managing land use and land-cover change: the New Jersey Pinelands biosphere reserve. Annals of the Association of American Geographers 89:220-237. http://dx.doi.org/10.1111/1467-8306.00143 


\section{APPENDIX 1.}

Transitions between land cover classes. For each combination, the total area in ha (ha), the expected area in terms of loss (exp.loss) and the relation of observed and expected loss (o/e) were calculated in the reference area, the total reserve, and each of the core, buffer and transition zones. For the definitions and abbreviations of classes see table 2 .

\section{Table A1.1: Reference area}

\begin{tabular}{|c|c|c|c|c|c|c|c|c|c|c|c|c|c|c|c|}
\hline \multirow[b]{3}{*}{1992} & \multicolumn{15}{|l|}{2005} \\
\hline & Class & & $\mathrm{S} / \mathrm{I}$ & W & $\mathrm{M} / \mathrm{B}$ & GLin & GLex & $\mathrm{Ar}$ & Fcon & Fdec & Fmix & Fcarr & $\mathrm{W} / \mathrm{H}$ & Loss & $\begin{array}{l}\text { Total } \\
92\end{array}$ \\
\hline & \multirow{3}{*}{$\mathrm{S} / \mathrm{I}$} & ha & 6513.5 & 56.9 & 0.5 & 378.0 & 9.6 & 229.3 & 21.2 & 76.7 & 52.7 & 1.0 & 522.0 & 1347.9 & 7861.5 \\
\hline & & exp.loss & 6513.5 & 83.2 & 2.9 & 207.9 & 4.2 & 518.8 & 320.8 & 68.2 & 87.0 & 7.4 & 47.6 & & \\
\hline & & $\mathrm{o} / \mathrm{e}$ & 0.0 & -0.3 & -0.8 & 0.8 & 1.3 & -0.6 & -0.9 & 0.1 & -0.4 & -0.9 & 10.0 & & \\
\hline & \multirow[t]{3}{*}{ W } & ha & 21.9 & 4299.7 & 25.1 & 23.0 & 1.0 & 6.1 & 4.3 & 30.8 & 17.1 & 15.2 & 54.3 & 198.9 & 4498.6 \\
\hline & & exp.loss & 19.2 & 4299.7 & 0.4 & 29.5 & 0.6 & 73.7 & 45.6 & 9.7 & 12.4 & 1.1 & 6.8 & & \\
\hline & & $\mathrm{o} / \mathrm{e}$ & 0.1 & 0.0 & 60.8 & -0.2 & 0.7 & -0.9 & -0.9 & 2.2 & 0.4 & 13.4 & 7.0 & & \\
\hline & \multirow[t]{3}{*}{$\mathrm{M} / \mathrm{B}$} & ha & 4.0 & 27.1 & 100.7 & 0.8 & 2.8 & 0.6 & 4.2 & 9.0 & 5.8 & 10.6 & 13.8 & 78.7 & 179.4 \\
\hline & & exp.loss & 7.2 & 4.4 & 100.7 & 11.0 & 0.2 & 27.6 & 17.0 & 3.6 & 4.6 & 0.4 & 2.5 & & \\
\hline & & $\mathrm{o} / \mathrm{e}$ & -0.4 & 5.1 & 0.0 & -0.9 & 11.4 & -1.0 & -0.8 & 1.5 & 0.2 & 25.9 & 4.4 & & \\
\hline & \multirow[t]{3}{*}{ GLin } & ha & 428.4 & 37.9 & 2.6 & 9598.1 & 104.3 & 3318.4 & 36.0 & 59.0 & 15.5 & 8.6 & 420.3 & 4430.9 & 14029.0 \\
\hline & & exp.loss & 469.3 & 289.2 & 9.9 & 9598.1 & 14.8 & 1802.7 & 1114.7 & 237.0 & 302.3 & 25.8 & 165.2 & & \\
\hline & & $\mathrm{o} / \mathrm{e}$ & -0.1 & -0.9 & -0.7 & 0.0 & 6.1 & 0.8 & -1.0 & -0.8 & -0.9 & -0.7 & 1.5 & & \\
\hline & \multirow[t]{3}{*}{ GLex } & ha & 2.4 & 1.9 & 7.1 & 47.1 & 86.9 & 0.5 & 3.1 & 5.3 & 1.2 & 2.8 & 16.1 & 87.7 & 174.6 \\
\hline & & exp.loss & 8.0 & 4.9 & 0.2 & 12.3 & 86.9 & 30.8 & 19.0 & 4.0 & 5.2 & 0.4 & 2.8 & & \\
\hline & & $\mathrm{o} / \mathrm{e}$ & -0.7 & -0.6 & 40.8 & 2.8 & 0.0 & -1.0 & -0.8 & 0.3 & -0.8 & 5.4 & 4.7 & & \\
\hline & \multirow[t]{3}{*}{$\mathrm{Ar}$} & ha & 265.2 & 8.6 & 0.0 & 1449.2 & 4.7 & 25372.2 & 18.8 & 25.1 & 5.0 & 0.3 & 290.2 & 2067.0 & 27439.1 \\
\hline & & exp.loss & 289.5 & 178.4 & 6.1 & 445.7 & 9.1 & 25372.2 & 687.6 & 146.2 & 186.5 & 15.9 & 101.9 & & \\
\hline & & $\mathrm{o} / \mathrm{e}$ & -0.1 & -1.0 & -1.0 & 2.3 & -0.5 & 0.0 & -1.0 & -0.8 & -1.0 & -1.0 & 1.8 & & \\
\hline & \multirow[t]{3}{*}{ Fcon } & ha & 118.8 & 3.6 & 1.6 & 4.7 & 2.2 & 4.5 & 16611.2 & 108.7 & 719.4 & 1.3 & 234.3 & 1199.2 & 17810.4 \\
\hline & & exp.loss & 139.4 & 85.9 & 3.0 & 214.5 & 4.4 & 535.3 & 16611.2 & 70.4 & 89.8 & 7.7 & 49.1 & & \\
\hline & & $\mathrm{o} / \mathrm{e}$ & -0.1 & -1.0 & -0.4 & -1.0 & -0.5 & -1.0 & 0.0 & 0.5 & 7.0 & -0.8 & 3.8 & & \\
\hline & \multirow[t]{3}{*}{ Fdec } & ha & 12.5 & 13.9 & 2.4 & 5.5 & 0.3 & 3.8 & 44.0 & 2828.5 & 156.8 & 25.1 & 37.9 & 302.2 & 3130.6 \\
\hline & & exp.loss & 28.8 & 17.8 & 0.6 & 44.4 & 0.9 & 110.8 & 68.5 & 2828.5 & 18.6 & 1.6 & 10.2 & & \\
\hline & & $\mathrm{o} / \mathrm{e}$ & -0.6 & -0.2 & 2.9 & -0.9 & -0.6 & -1.0 & -0.4 & 0.0 & 7.4 & 14.8 & 2.7 & & \\
\hline & \multirow[t]{3}{*}{ Fmix } & ha & 7.8 & 5.9 & 2.0 & 3.4 & 0.6 & 1.1 & 168.2 & 169.2 & 3406.3 & 3.6 & 30.1 & 392.0 & 3798.3 \\
\hline & & exp.loss & 37.9 & 23.4 & 0.8 & 58.4 & 1.2 & 145.7 & 90.1 & 19.1 & 3406.3 & 2.1 & 13.4 & & \\
\hline & & $\mathrm{o} / \mathrm{e}$ & -0.8 & -0.7 & 1.5 & -0.9 & -0.5 & -1.0 & 0.9 & 7.8 & 0.0 & 0.7 & 1.3 & & \\
\hline & \multirow[t]{3}{*}{ Fcarr } & ha & 6.9 & 9.3 & 4.0 & 0.9 & 0.1 & 0.5 & 1.2 & 8.9 & 4.9 & 317.7 & 1.5 & 38.1 & 355.8 \\
\hline & & exp.loss & 3.5 & 2.1 & 0.1 & 5.4 & 0.1 & 13.4 & 8.3 & 1.8 & 2.2 & 317.7 & 1.2 & & \\
\hline & & $\mathrm{o} / \mathrm{e}$ & 1.0 & 3.3 & 52.8 & -0.8 & 0.1 & -1.0 & -0.9 & 4.0 & 1.2 & 0.0 & 0.2 & & \\
\hline & \multirow[t]{3}{*}{$\mathrm{W} / \mathrm{H}$} & ha & 169.6 & 187.9 & 13.9 & 114.9 & 25.0 & 67.2 & 1023.0 & 492.1 & 478.9 & 28.6 & 1038.1 & 2601.2 & 3639.2 \\
\hline & & exp.loss & 244.7 & 150.8 & 5.2 & 376.8 & 7.7 & 940.0 & 581.3 & 123.6 & 157.6 & 13.4 & 1038.1 & & \\
\hline & & $\mathrm{o} / \mathrm{e}$ & -0.3 & 0.2 & 1.7 & -0.7 & 2.2 & -0.9 & 0.8 & 3.0 & 2.0 & 1.1 & 0.0 & & \\
\hline & Gain & & 1037.7 & 352.9 & 59.3 & 2027.5 & 150.7 & 3632.0 & 1324.1 & 984.7 & 1457.3 & 97.0 & 1620.5 & & \\
\hline & $\begin{array}{l}\text { Total } \\
05\end{array}$ & & 7551.2 & 4652.6 & 160.0 & 11625.6 & 237.5 & 29004.2 & 17935.2 & 3813.2 & 4863.6 & 414.8 & 2658.6 & & 82916.5 \\
\hline
\end{tabular}


Table A1.2: Total reserve

\begin{tabular}{|c|c|c|c|c|c|c|c|c|c|c|c|c|c|c|c|}
\hline \multirow[b]{3}{*}{1992} & \multicolumn{15}{|l|}{2005} \\
\hline & Class & & S/I & W & $\mathrm{M} / \mathrm{B}$ & GLin & GLex & $\mathrm{Ar}$ & Fcon & Fdec & Fmix & Fcarr & $\mathrm{W} / \mathrm{H}$ & Loss & $\begin{array}{l}\text { Total } \\
92\end{array}$ \\
\hline & \multirow{3}{*}{$\mathrm{S} / \mathrm{I}$} & ha & 914.7 & 9.1 & 0.8 & 72.5 & 5.7 & 24.2 & 10.4 & 14.7 & 6.8 & 0.3 & 99.5 & 244.1 & 1158.8 \\
\hline & & exp.loss & 914.7 & 25.5 & 2.3 & 29.5 & 3.3 & 48.8 & 93.1 & 12.7 & 16.4 & 3.6 & 9.0 & & \\
\hline & & $\mathrm{o} / \mathrm{e}$ & 0.0 & -0.6 & -0.6 & 1.5 & 0.7 & -0.5 & -0.9 & 0.2 & -0.6 & -0.9 & 10.1 & & \\
\hline & \multirow[t]{3}{*}{ W } & ha & 2.6 & 2608.1 & 18.0 & 16.2 & 4.9 & 2.4 & 15.9 & 17.6 & 11.1 & 11.5 & 15.0 & 115.3 & 2723.4 \\
\hline & & exp.loss & 4.9 & 2608.1 & 1.2 & 14.9 & 1.7 & 24.6 & 47.0 & 6.4 & 8.3 & 1.8 & 4.5 & & \\
\hline & & $\mathrm{o} / \mathrm{e}$ & -0.5 & 0.0 & 14.4 & 0.1 & 1.9 & -0.9 & -0.7 & 1.7 & 0.3 & 5.4 & 2.3 & & \\
\hline & \multirow[t]{3}{*}{$\mathrm{M} / \mathrm{B}$} & ha & 0.0 & 12.8 & 148.5 & 1.7 & 4.5 & 0.3 & 3.4 & 10.7 & 8.0 & 4.0 & 12.2 & 57.6 & 206.1 \\
\hline & & exp.loss & 2.2 & 5.8 & 148.5 & 6.8 & 0.8 & 11.2 & 21.3 & 2.9 & 3.8 & 0.8 & 2.1 & & \\
\hline & & $\mathrm{o} / \mathrm{e}$ & -1.0 & 1.2 & 0.0 & -0.7 & 4.8 & -1.0 & -0.8 & 2.7 & 1.1 & 3.8 & 5.0 & & \\
\hline & \multirow[t]{3}{*}{ GLin } & ha & 71.4 & 9.7 & 1.7 & 2610.0 & 141.7 & 636.8 & 20.6 & 15.4 & 8.0 & 3.8 & 114.0 & 1023.2 & 3633.2 \\
\hline & & exp.loss & 43.9 & 116.3 & 10.6 & 2610.0 & 15.2 & 222.5 & 424.6 & 58.0 & 74.9 & 16.3 & 40.9 & & \\
\hline & & $\mathrm{o} / \mathrm{e}$ & 0.6 & -0.9 & -0.8 & 0.0 & 8.3 & 1.9 & -1.0 & -0.7 & -0.9 & -0.8 & 1.8 & & \\
\hline & \multirow[t]{3}{*}{ GLex } & ha & 0.2 & 1.3 & 11.4 & 10.9 & 109.4 & 1.2 & 10.1 & 11.8 & 14.3 & 1.5 & 39.8 & 102.4 & 211.9 \\
\hline & & exp.loss & 3.9 & 10.4 & 0.9 & 12.1 & 109.4 & 19.9 & 38.1 & 5.2 & 6.7 & 1.5 & 3.7 & & \\
\hline & & $\mathrm{o} / \mathrm{e}$ & -1.0 & -0.9 & 11.0 & -0.1 & 0.0 & -0.9 & -0.7 & 1.3 & 1.1 & 0.1 & 9.9 & & \\
\hline & \multirow[t]{3}{*}{$\mathrm{Ar}$} & ha & 19.4 & 0.7 & 2.1 & 384.4 & 3.8 & 4506.0 & 12.3 & 17.9 & 9.6 & 0.0 & 68.7 & 518.9 & 5024.9 \\
\hline & & exp.loss & 24.4 & 64.5 & 5.9 & 74.6 & 8.4 & 4506.0 & 235.7 & 32.2 & 41.5 & 9.1 & 22.7 & & \\
\hline & & $\mathrm{o} / \mathrm{e}$ & -0.2 & -1.0 & -0.6 & 4.2 & -0.5 & 0.0 & -0.9 & -0.4 & -0.8 & -1.0 & 2.0 & & \\
\hline & \multirow[t]{3}{*}{ Fcon } & ha & 1.7 & 4.6 & 3.0 & 3.8 & 9.6 & 0.8 & 9020.4 & 34.6 & 241.3 & 2.3 & 56.9 & 358.5 & 9378.9 \\
\hline & & exp.loss & 21.5 & 56.9 & 5.2 & 65.7 & 7.4 & 108.8 & 9020.4 & 28.4 & 36.6 & 8.0 & 20.0 & & \\
\hline & & $\mathrm{o} / \mathrm{e}$ & -0.9 & -0.9 & -0.4 & -0.9 & 0.3 & -1.0 & 0.0 & 0.2 & 5.6 & -0.7 & 1.8 & & \\
\hline & \multirow[t]{3}{*}{ Fdec } & ha & 3.7 & 8.7 & 1.8 & 1.6 & 0.4 & 0.1 & 17.2 & 863.8 & 63.8 & 1.9 & 3.0 & 102.2 & 966.0 \\
\hline & & exp.loss & 4.1 & 10.8 & 1.0 & 12.5 & 1.4 & 20.7 & 39.5 & 863.8 & 7.0 & 1.5 & 3.8 & & \\
\hline & & $\mathrm{o} / \mathrm{e}$ & -0.1 & -0.2 & 0.8 & -0.9 & -0.7 & -1.0 & -0.6 & 0.0 & 8.2 & 0.3 & -0.2 & & \\
\hline & \multirow[t]{3}{*}{ Fmix } & ha & 0.3 & 1.6 & 1.0 & 0.6 & 0.6 & 0.1 & 33.2 & 27.9 & 1106.3 & 3.7 & 7.0 & 76.1 & 1182.4 \\
\hline & & exp.loss & 3.1 & 8.2 & 0.7 & 9.4 & 1.1 & 15.6 & 29.8 & 4.1 & 1106.3 & 1.1 & 2.9 & & \\
\hline & & $\mathrm{o} / \mathrm{e}$ & -0.9 & -0.8 & 0.3 & -0.9 & -0.4 & -1.0 & 0.1 & 5.8 & 0.0 & 2.2 & 1.5 & & \\
\hline & \multirow[t]{3}{*}{ Fcarr } & ha & 0.0 & 4.5 & 5.8 & 0.3 & 0.0 & 0.0 & 2.4 & 19.4 & 6.3 & 343.0 & 1.6 & 40.2 & 383.2 \\
\hline & & exp.loss & 1.5 & 4.1 & 0.4 & 4.7 & 0.5 & 7.8 & 15.0 & 2.0 & 2.6 & 343.0 & 1.4 & & \\
\hline & & $\mathrm{o} / \mathrm{e}$ & -1.0 & 0.1 & 14.4 & -0.9 & -1.0 & -1.0 & -0.8 & 8.5 & 1.4 & 0.0 & 0.1 & & \\
\hline & \multirow[t]{3}{*}{$\mathrm{W} / \mathrm{H}$} & ha & 9.8 & 48.8 & 52.4 & 29.4 & 73.8 & 11.9 & 748.2 & 317.9 & 268.6 & 8.4 & 534.1 & 1569.2 & 2103.3 \\
\hline & & exp.loss & 61.7 & 163.4 & 14.9 & 188.8 & 21.4 & 312.6 & 596.7 & 81.5 & 105.2 & 22.9 & 534.1 & & \\
\hline & & $\mathrm{o} / \mathrm{e}$ & -0.8 & -0.7 & 2.5 & -0.8 & 2.5 & -1.0 & 0.3 & 2.9 & 1.6 & -0.6 & 0.0 & & \\
\hline & Gain & & 109.1 & 101.9 & 98.1 & 521.5 & 244.9 & 677.7 & 873.8 & 487.9 & 637.8 & 37.5 & 417.7 & & \\
\hline & $\begin{array}{l}\text { Total } \\
05\end{array}$ & & 1023.8 & 2710.0 & 246.6 & 3131.5 & 354.3 & 5183.7 & 9894.1 & 1351.7 & 1744.1 & 380.5 & 951.8 & & 26972.1 \\
\hline
\end{tabular}


Table A1.3: Core zone

\begin{tabular}{|c|c|c|c|c|c|c|c|c|c|c|c|c|c|c|c|}
\hline \multirow[b]{3}{*}{1992} & \multicolumn{15}{|l|}{2005} \\
\hline & Class & & $\mathrm{S} / \mathrm{I}$ & W & $\mathrm{M} / \mathrm{B}$ & GLin & GLex & $\mathrm{Ar}$ & Fcon & Fdec & Fmix & Fcarr & $\mathrm{W} / \mathrm{H}$ & Loss & $\begin{array}{l}\text { Total } \\
92\end{array}$ \\
\hline & \multirow[t]{3}{*}{$\mathrm{S} / \mathrm{I}$} & ha & 2.0 & 0.0 & 0.0 & 1.1 & 0.0 & 0.0 & 1.9 & 0.0 & 0.1 & 0.0 & 7.5 & 10.5 & 12.5 \\
\hline & & exp.loss & 2.0 & 0.2 & 0.9 & 0.1 & 0.2 & 0.0 & 4.9 & 1.4 & 1.5 & 0.8 & 0.6 & & \\
\hline & & $\mathrm{o} / \mathrm{e}$ & 1.00 & 0.00 & 0.00 & 17.70 & 0.00 & 0.00 & 0.39 & 0.00 & 0.04 & 0.00 & 12.03 & & \\
\hline & \multirow[t]{3}{*}{ W } & ha & 0.0 & 9.7 & 2.4 & 0.0 & 0.0 & 0.0 & 1.6 & 0.1 & 0.2 & 0.8 & 0.0 & 5.1 & 14.8 \\
\hline & & exp.loss & 0.0 & 9.7 & 0.4 & 0.0 & 0.1 & 0.0 & 2.4 & 0.7 & 0.7 & 0.4 & 0.3 & & \\
\hline & & $\mathrm{o} / \mathrm{e}$ & 0.00 & 1.00 & 5.50 & 0.00 & 0.00 & 0.00 & 0.68 & 0.11 & 0.28 & 2.02 & 0.00 & & \\
\hline & \multirow[t]{3}{*}{$\mathrm{M} / \mathrm{B}$} & ha & 0 & 1 & 56 & 0 & 0 & 0 & 0 & 1 & 0 & 2 & 0 & 5 & 62 \\
\hline & & exp.loss & 0.0 & 0.1 & 56.4 & 0.0 & 0.1 & 0.0 & 2.8 & 0.8 & 0.8 & 0.5 & 0.4 & & \\
\hline & & $\mathrm{o} / \mathrm{e}$ & 0.0 & 13.3 & 1.0 & 0.0 & 0.0 & 0.0 & 0.0 & 1.4 & 0.3 & 5.0 & 1.2 & & \\
\hline & \multirow[t]{3}{*}{ GLin } & ha & 0.0 & 0.0 & 0.0 & 3.4 & 11.9 & 0.4 & 0.0 & 0.5 & 0.0 & 0.0 & 1.3 & 14.1 & 17.6 \\
\hline & & exp.loss & 0.0 & 0.2 & 1.2 & 3.4 & 0.3 & 0.0 & 6.6 & 1.8 & 2.0 & 1.1 & 0.8 & & \\
\hline & & $\mathrm{o} / \mathrm{e}$ & 0.00 & 0.00 & 0.00 & 1.00 & 42.07 & 54.99 & 0.00 & 0.29 & 0.00 & 0.00 & 1.50 & & \\
\hline & \multirow[t]{3}{*}{ GLex } & ha & 0.0 & 0.0 & 0.0 & 0.0 & 3.5 & 0.0 & 0.0 & 0.1 & 0.0 & 0.1 & 0.8 & 1.0 & 4.6 \\
\hline & & exp.loss & 0.0 & 0.0 & 0.1 & 0.0 & 3.5 & 0.0 & 0.5 & 0.1 & 0.1 & 0.1 & 0.1 & & \\
\hline & & $\mathrm{o} / \mathrm{e}$ & 0.00 & 0.00 & 0.00 & 0.00 & 1.00 & 0.00 & 0.00 & 0.63 & 0.00 & 1.16 & 13.65 & & \\
\hline & \multirow[t]{3}{*}{$\mathrm{Ar}$} & ha & 0.0 & 0.0 & 0.0 & 0.0 & 0.0 & 0.0 & 0.0 & 0.0 & 0.0 & 0.0 & 0.0 & 0.0 & 0.0 \\
\hline & & exp.loss & 0.0 & 0.0 & 0.0 & 0.0 & 0.0 & 0.0 & 0.0 & 0.0 & 0.0 & 0.0 & 0.0 & & \\
\hline & & $\mathrm{o} / \mathrm{e}$ & 0.00 & 0.00 & 0.00 & 0.00 & 0.00 & \#DIV/0! & 0.00 & 7.76 & 0.00 & 0.00 & 0.00 & & \\
\hline & \multirow[t]{3}{*}{ Fcon } & ha & 0.0 & 0.1 & 1.3 & 0.0 & 0.0 & 0.0 & 342.1 & 0.8 & 7.1 & 1.0 & 0.0 & 10.3 & 352.4 \\
\hline & & exp.loss & 0.0 & 0.3 & 1.6 & 0.1 & 0.4 & 0.0 & 342.1 & 2.5 & 2.7 & 1.6 & 1.1 & & \\
\hline & & $\mathrm{o} / \mathrm{e}$ & 0.00 & 0.23 & 0.81 & 0.00 & 0.00 & 0.00 & 1.00 & 0.33 & 2.66 & 0.65 & 0.00 & & \\
\hline & \multirow[t]{3}{*}{ Fdec } & ha & 0.0 & 0.6 & 0.5 & 0.0 & 0.0 & 0.0 & 0.9 & 72.3 & 3.6 & 0.0 & 0.2 & 5.8 & 78.1 \\
\hline & & exp.loss & 0.0 & 0.1 & 0.5 & 0.0 & 0.1 & 0.0 & 3.1 & 72.3 & 0.9 & 0.5 & 0.4 & & \\
\hline & & $\mathrm{o} / \mathrm{e}$ & 0.00 & 5.68 & 0.84 & 0.00 & 0.00 & 0.00 & 0.30 & 1.00 & 3.88 & 0.00 & 0.61 & & \\
\hline & \multirow[t]{3}{*}{ Fmix } & ha & 0.0 & 0.0 & 0.9 & 0.0 & 0.0 & 0.0 & 2.3 & 1.8 & 85.3 & 0.0 & 0.0 & 5.0 & 90.3 \\
\hline & & exp.loss & 0.0 & 0.1 & 0.5 & 0.0 & 0.1 & 0.0 & 2.7 & 0.7 & 85.3 & 0.5 & 0.3 & & \\
\hline & & $\mathrm{o} / \mathrm{e}$ & 0.00 & 0.41 & 1.96 & 0.00 & 0.00 & 0.00 & 0.84 & 2.36 & 1.00 & 0.00 & 0.00 & & \\
\hline & \multirow[t]{3}{*}{ Fcarr } & ha & 0.0 & 0.2 & 0.5 & 0.0 & 0.0 & 0.0 & 0.0 & 1.2 & 2.4 & 57.8 & 0.0 & 4.3 & 62.1 \\
\hline & & exp.loss & 0.0 & 0.1 & 0.4 & 0.0 & 0.1 & 0.0 & 2.2 & 0.6 & 0.6 & 57.8 & 0.3 & & \\
\hline & & $\mathrm{o} / \mathrm{e}$ & 0.00 & 2.04 & 1.32 & 0.00 & 0.00 & 0.00 & 0.02 & 2.07 & 3.65 & 1.00 & 0.00 & & \\
\hline & \multirow[t]{3}{*}{$\mathrm{W} / \mathrm{H}$} & ha & 0.0 & 0.6 & 2.4 & 0.0 & 0.1 & 0.0 & 15.6 & 22.7 & 9.2 & 0.8 & 35.9 & 51.3 & 87.2 \\
\hline & & exp.loss & 0.1 & 0.9 & 4.5 & 0.3 & 1.1 & 0.0 & 25.5 & 7.0 & 7.5 & 4.4 & 35.9 & & \\
\hline & & $\mathrm{o} / \mathrm{e}$ & 0.00 & 0.71 & 0.52 & 0.00 & 0.11 & 0.00 & 0.61 & 3.23 & 1.22 & 0.18 & 1.00 & & \\
\hline & Gain & & 0.0 & 2.7 & 7.9 & 1.1 & 12.0 & 0.4 & 22.5 & 28.3 & 22.7 & 5.1 & 10.2 & & \\
\hline & $\begin{array}{l}\text { Total } \\
05 \\
\end{array}$ & & 2.0 & 12.4 & 64.3 & 4.5 & 15.5 & 0.4 & 364.6 & 100.6 & 108.0 & 62.9 & 46.1 & & 781.5 \\
\hline
\end{tabular}


Table A1.4: Buffer zone

\begin{tabular}{|c|c|c|c|c|c|c|c|c|c|c|c|c|c|c|c|}
\hline \multirow[b]{3}{*}{1992} & \multicolumn{15}{|l|}{2005} \\
\hline & Class & & $\mathrm{S} / \mathrm{I}$ & W & M/B & GLin & GLex & $\mathrm{Ar}$ & Fcon & Fdec & Fmix & Fcarr & $\mathrm{W} / \mathrm{H}$ & Loss & $\begin{array}{l}\text { Total } \\
92\end{array}$ \\
\hline & \multirow[t]{3}{*}{$\mathrm{S} / \mathrm{I}$} & ha & 14.9 & 1.6 & 0.8 & 6.9 & 1.0 & 3.0 & 5.7 & 6.9 & 2.0 & 0.3 & 16.0 & 44.2 & 59.2 \\
\hline & & exp.loss & 14.9 & 9.5 & 0.6 & 3.6 & 1.0 & 1.8 & 18.0 & 3.1 & 3.9 & 1.1 & 1.5 & & \\
\hline & & $\mathrm{o} / \mathrm{e}$ & 1.00 & 0.17 & 1.31 & 1.91 & 1.08 & 1.68 & 0.32 & 2.21 & 0.50 & 0.26 & 10.50 & & \\
\hline & \multirow[t]{3}{*}{ W } & ha & 0.7 & 2417.2 & 15.7 & 12.1 & 4.9 & 1.2 & 11.0 & 13.9 & 7.2 & 10.3 & 8.3 & 85.2 & 2502.4 \\
\hline & & exp.loss & 0.2 & 2417.2 & 1.6 & 8.8 & 2.4 & 4.3 & 44.2 & 7.6 & 9.7 & 2.7 & 3.7 & & \\
\hline & & $\mathrm{o} / \mathrm{e}$ & 4.09 & 1.00 & 9.88 & 1.37 & 2.06 & 0.27 & 0.25 & 1.82 & 0.74 & 3.75 & 2.23 & & \\
\hline & \multirow[t]{3}{*}{$\mathrm{M} / \mathrm{B}$} & ha & 0 & 11 & 84 & 1 & 4 & 0 & 3 & 10 & 5 & 2 & 9 & 44 & 128 \\
\hline & & exp.loss & 0.1 & 9.6 & 84.1 & 3.7 & 1.0 & 1.8 & 18.3 & 3.2 & 4.0 & 1.1 & 1.5 & & \\
\hline & & $\mathrm{o} / \mathrm{e}$ & 0.0 & 1.2 & 1.0 & 0.3 & 4.3 & 0.0 & 0.2 & 3.0 & 1.2 & 1.4 & 5.8 & & \\
\hline & \multirow[t]{3}{*}{ GLin } & ha & 2.8 & 6.2 & 1.1 & 834.8 & 81.0 & 98.7 & 10.8 & 5.3 & 3.1 & 3.0 & 39.4 & 251.4 & 1086.2 \\
\hline & & exp.loss & 0.5 & 58.7 & 4.0 & 834.8 & 6.0 & 10.9 & 111.5 & 19.2 & 24.4 & 6.9 & 9.4 & & \\
\hline & & $\mathrm{o} / \mathrm{e}$ & 6.10 & 0.11 & 0.28 & 1.00 & 13.60 & 9.06 & 0.10 & 0.28 & 0.13 & 0.44 & 4.18 & & \\
\hline & \multirow[t]{3}{*}{ GLex } & ha & 0.0 & 1.3 & 11.3 & 4.4 & 92.2 & 0.8 & 10.0 & 11.2 & 14.3 & 1.0 & 36.6 & 90.9 & 183.0 \\
\hline & & exp.loss & 0.2 & 19.9 & 1.4 & 7.6 & 92.2 & 3.7 & 37.8 & 6.5 & 8.3 & 2.3 & 3.2 & & \\
\hline & & $\mathrm{o} / \mathrm{e}$ & 0.00 & 0.06 & 8.32 & 0.58 & 1.00 & 0.23 & 0.26 & 1.72 & 1.73 & 0.42 & 11.43 & & \\
\hline & \multirow[t]{3}{*}{$\mathrm{Ar}$} & ha & 0.2 & 0.3 & 0.0 & 79.1 & 0.0 & 356.7 & 0.2 & 0.5 & 0.1 & 0.0 & 6.6 & 87.1 & 443.8 \\
\hline & & exp.loss & 0.2 & 19.4 & 1.3 & 7.4 & 2.0 & 356.7 & 36.9 & 6.4 & 8.1 & 2.3 & 3.1 & & \\
\hline & & $\mathrm{o} / \mathrm{e}$ & 1.00 & 0.02 & 0.02 & 10.70 & 0.00 & 1.00 & 0.01 & 0.08 & 0.01 & 0.01 & 2.11 & & \\
\hline & \multirow[t]{3}{*}{ Fcon } & ha & 0.0 & 4.3 & 1.7 & 1.7 & 3.5 & 0.1 & 4318.2 & 23.9 & 150.2 & 1.3 & 20.8 & 207.6 & 4525.8 \\
\hline & & exp.loss & 0.6 & 75.1 & 5.1 & 28.5 & 7.6 & 13.9 & 4318.2 & 24.6 & 31.2 & 8.8 & 12.1 & & \\
\hline & & $\mathrm{o} / \mathrm{e}$ & 0.09 & 0.06 & 0.34 & 0.06 & 0.46 & 0.01 & 1.00 & 0.97 & 4.82 & 0.15 & 1.72 & & \\
\hline & \multirow[t]{3}{*}{ Fdec } & ha & 0.2 & 7.4 & 1.3 & 0.6 & 0.4 & 0.0 & 8.9 & 497.2 & 27.7 & 1.9 & 1.8 & 50.2 & 547.4 \\
\hline & & exp.loss & 0.1 & 11.6 & 0.8 & 4.4 & 1.2 & 2.1 & 22.0 & 497.2 & 4.8 & 1.4 & 1.9 & & \\
\hline & & $\mathrm{o} / \mathrm{e}$ & 2.42 & 0.64 & 1.68 & 0.13 & 0.30 & 0.00 & 0.41 & 1.00 & 5.77 & 1.39 & 0.95 & & \\
\hline & \multirow[t]{3}{*}{ Fmix } & ha & 0.0 & 1.6 & 0.0 & 0.5 & 0.1 & 0.0 & 13.2 & 17.3 & 641.8 & 3.7 & 3.9 & 40.4 & 682.1 \\
\hline & & exp.loss & 0.1 & 9.5 & 0.6 & 3.6 & 1.0 & 1.8 & 18.0 & 3.1 & 641.8 & 1.1 & 1.5 & & \\
\hline & & $\mathrm{o} / \mathrm{e}$ & 0.00 & 0.17 & 0.00 & 0.15 & 0.08 & 0.00 & 0.73 & 5.57 & 1.00 & 3.29 & 2.54 & & \\
\hline & \multirow[t]{3}{*}{ Fcarr } & ha & 0.0 & 4.4 & 4.9 & 0.2 & 0.0 & 0.0 & 2.4 & 15.7 & 3.6 & 265.8 & 1.6 & 32.8 & 298.6 \\
\hline & & exp.loss & 0.1 & 7.2 & 0.5 & 2.7 & 0.7 & 1.3 & 13.7 & 2.4 & 3.0 & 265.8 & 1.2 & & \\
\hline & & $\mathrm{o} / \mathrm{e}$ & 0.70 & 0.60 & 9.99 & 0.08 & 0.00 & 0.00 & 0.17 & 6.64 & 1.20 & 1.00 & 1.38 & & \\
\hline & \multirow[t]{3}{*}{$\mathrm{W} / \mathrm{H}$} & ha & 0.4 & 35.2 & 48.9 & 5.7 & 65.6 & 1.7 & 347.5 & 214.8 & 179.6 & 4.7 & 256.7 & 903.9 & 1160.6 \\
\hline & & exp.loss & 1.6 & 200.7 & 13.7 & 76.3 & 20.4 & 37.2 & 381.2 & 65.8 & 83.3 & 23.7 & 256.7 & & \\
\hline & & $\mathrm{o} / \mathrm{e}$ & 0.24 & 0.18 & 3.57 & 0.07 & 3.22 & 0.05 & 0.91 & 3.26 & 2.16 & 0.20 & 1.00 & & \\
\hline & Gain & & 4.3 & 73.7 & 85.8 & 112.2 & 160.6 & 105.4 & 412.7 & 319.0 & 392.4 & 27.7 & 144.0 & & \\
\hline & $\begin{array}{l}\text { Total } \\
05 \\
\end{array}$ & & 19.3 & 2490.9 & 169.9 & 947.0 & 252.7 & 462.2 & 4730.9 & 816.3 & 1034.2 & 293.5 & 400.7 & & 11617.6 \\
\hline
\end{tabular}


Table A1.5: Transition zone

\begin{tabular}{|c|c|c|c|c|c|c|c|c|c|c|c|c|c|c|c|}
\hline \multirow[b]{3}{*}{1992} & \multicolumn{15}{|l|}{2005} \\
\hline & Class & & $\mathrm{S} / \mathrm{I}$ & W & $\mathrm{M} / \mathrm{B}$ & GLin & GLex & $\mathrm{Ar}$ & Fcon & Fdec & Fmix & Fcarr & $\mathrm{W} / \mathrm{H}$ & Loss & $\begin{array}{l}\text { Total } \\
92\end{array}$ \\
\hline & \multirow[t]{3}{*}{$\mathrm{S} / \mathrm{I}$} & ha & 891.5 & 2.6 & 0.0 & 64.4 & 4.6 & 20.2 & 2.0 & 7.8 & 2.5 & 0.0 & 59.7 & 163.8 & 1055.2 \\
\hline & & exp.loss & 891.5 & 2.3 & 0.1 & 27.1 & 1.0 & 55.6 & 58.7 & 5.6 & 7.1 & 0.3 & 6.0 & & \\
\hline & & $\mathrm{o} / \mathrm{e}$ & 1.00 & 1.14 & 0.00 & 2.37 & 4.68 & 0.36 & 0.03 & 1.40 & 0.35 & 0.14 & 9.98 & & \\
\hline & \multirow[t]{3}{*}{ W } & ha & 1.9 & 148.6 & 0.0 & 3.2 & 0.0 & 1.2 & 1.5 & 3.6 & 1.4 & 0.4 & 5.9 & 19.2 & 167.7 \\
\hline & & exp.loss & 1.5 & 148.6 & 0.0 & 3.0 & 0.1 & 6.1 & 6.4 & 0.6 & 0.8 & 0.0 & 0.7 & & \\
\hline & & $\mathrm{o} / \mathrm{e}$ & 1.28 & 1.00 & 0.00 & 1.07 & 0.00 & 0.20 & 0.24 & 5.95 & 1.79 & 12.87 & 8.98 & & \\
\hline & \multirow[t]{3}{*}{$\mathrm{M} / \mathrm{B}$} & ha & 0 & 0 & 6 & 1 & 0 & 0 & 0 & 0 & 0 & 0 & 3 & 4 & 10 \\
\hline & & exp.loss & 0.3 & 0.1 & 5.8 & 0.7 & 0.0 & 1.4 & 1.5 & 0.1 & 0.2 & 0.0 & 0.2 & & \\
\hline & & $\mathrm{o} / \mathrm{e}$ & 0.0 & 1.6 & 1.0 & 1.1 & 0.0 & 0.2 & 0.0 & 1.2 & 1.6 & 2.5 & 19.2 & & \\
\hline & \multirow[t]{3}{*}{ GLin } & ha & 67.1 & 3.5 & 0.6 & 1626.1 & 48.8 & 451.1 & 7.6 & 9.1 & 4.5 & 0.8 & 69.7 & 662.7 & 2288.9 \\
\hline & & exp.loss & 59.6 & 10.0 & 0.6 & 1626.1 & 4.4 & 245.5 & 259.1 & 24.6 & 31.3 & 1.4 & 26.4 & & \\
\hline & & $\mathrm{o} / \mathrm{e}$ & 1.13 & 0.35 & 1.06 & 1.00 & 11.16 & 1.84 & 0.03 & 0.37 & 0.14 & 0.59 & 2.64 & & \\
\hline & \multirow[t]{3}{*}{ GLex } & ha & 0.2 & 0.0 & 0.1 & 4.0 & 5.4 & 0.2 & 0.1 & 0.5 & 0.0 & 0.2 & 1.0 & 6.4 & 11.7 \\
\hline & & exp.loss & 0.5 & 0.1 & 0.0 & 1.0 & 5.4 & 2.0 & 2.1 & 0.2 & 0.3 & 0.0 & 0.2 & & \\
\hline & & $\mathrm{o} / \mathrm{e}$ & 0.37 & 0.00 & 26.50 & 4.07 & 1.00 & 0.12 & 0.03 & 2.66 & 0.12 & 17.63 & 4.65 & & \\
\hline & \multirow[t]{3}{*}{$\mathrm{Ar}$} & ha & 18.3 & 0.4 & 2.1 & 275.6 & 3.8 & 3606.8 & 8.9 & 15.4 & 9.5 & 0.0 & 57.8 & 391.9 & 3998.7 \\
\hline & & exp.loss & 43.5 & 7.3 & 0.4 & 87.4 & 3.2 & 3606.8 & 189.1 & 17.9 & 22.8 & 1.0 & 19.3 & & \\
\hline & & $\mathrm{o} / \mathrm{e}$ & 0.42 & 0.06 & 5.10 & 3.15 & 1.20 & 1.00 & 0.05 & 0.86 & 0.42 & 0.00 & 3.00 & & \\
\hline & \multirow[t]{3}{*}{ Fcon } & ha & 1.5 & 0.2 & 0.0 & 2.0 & 3.0 & 0.6 & 3952.0 & 9.7 & 74.3 & 0.0 & 34.6 & 126.1 & 4078.1 \\
\hline & & exp.loss & 14.4 & 2.4 & 0.1 & 28.9 & 1.1 & 59.1 & 3952.0 & 5.9 & 7.5 & 0.3 & 6.4 & & \\
\hline & & $\mathrm{o} / \mathrm{e}$ & 0.11 & 0.10 & 0.00 & 0.07 & 2.87 & 0.01 & 1.00 & 1.64 & 9.87 & 0.00 & 5.43 & & \\
\hline & \multirow[t]{3}{*}{ Fdec } & ha & 3.4 & 0.8 & 0.0 & 1.0 & 0.0 & 0.1 & 7.1 & 278.1 & 31.7 & 0.0 & 1.0 & 45.0 & 323.2 \\
\hline & & exp.loss & 3.5 & 0.6 & 0.0 & 7.1 & 0.3 & 14.6 & 15.4 & 278.1 & 1.9 & 0.1 & 1.6 & & \\
\hline & & $\mathrm{o} / \mathrm{e}$ & 0.97 & 1.27 & 0.00 & 0.15 & 0.00 & 0.00 & 0.46 & 1.00 & 17.06 & 0.00 & 0.61 & & \\
\hline & \multirow[t]{3}{*}{ Fmix } & ha & 0.3 & 0.0 & 0.0 & 0.1 & 0.0 & 0.1 & 15.6 & 8.5 & 326.7 & 0.0 & 3.1 & 27.5 & 354.2 \\
\hline & & exp.loss & 2.2 & 0.4 & 0.0 & 4.4 & 0.2 & 9.0 & 9.5 & 0.9 & 326.7 & 0.0 & 1.0 & & \\
\hline & & $\mathrm{o} / \mathrm{e}$ & 0.12 & 0.00 & 0.00 & 0.02 & 0.00 & 0.01 & 1.64 & 9.41 & 1.00 & 0.00 & 3.17 & & \\
\hline & \multirow[t]{3}{*}{ Fcarr } & ha & 0.0 & 0.0 & 0.0 & 0.0 & 0.0 & 0.0 & 0.0 & 0.3 & 0.3 & 18.3 & 0.0 & 0.6 & 19.0 \\
\hline & & exp.loss & 0.0 & 0.0 & 0.0 & 0.1 & 0.0 & 0.2 & 0.2 & 0.0 & 0.0 & 18.3 & 0.0 & & \\
\hline & & $\mathrm{o} / \mathrm{e}$ & 0.00 & 0.00 & 0.00 & 0.00 & 0.00 & 0.00 & 0.21 & 15.03 & 11.43 & 1.00 & 0.00 & & \\
\hline & \multirow[t]{3}{*}{$\mathrm{W} / \mathrm{H}$} & ha & 9.5 & 10.0 & 0.8 & 19.9 & 7.3 & 9.7 & 323.4 & 76.1 & 69.9 & 2.8 & 204.6 & 529.3 & 733.9 \\
\hline & & exp.loss & 41.7 & 7.0 & 0.4 & 83.9 & 3.1 & 171.8 & 181.4 & 17.2 & 21.9 & 1.0 & 204.6 & & \\
\hline & & $\mathrm{o} / \mathrm{e}$ & 0.23 & 1.43 & 1.98 & 0.24 & 2.37 & 0.06 & 1.78 & 4.43 & 3.19 & 2.99 & 1.00 & & \\
\hline & Gain & & 102.2 & 17.5 & 3.6 & 370.9 & 67.6 & 483.4 & 366.2 & 131.1 & 194.4 & 4.3 & 235.5 & & \\
\hline & $\begin{array}{l}\text { Total } \\
05\end{array}$ & & 993.6 & 166.1 & 9.4 & 1997.1 & 73.0 & 4090.2 & 4318.2 & 409.3 & 521.1 & 22.7 & 440.1 & & 13040.8 \\
\hline
\end{tabular}

